\title{
ALKOR - Bericht
}

CAU Kiel Master Course Marine Geosciences:

Measuring Techniques in Shallow water

Cruise No. AL552

\author{
16.3.2021 - 27.3.2021, \\ Kiel (Germany) - Kiel (Germany) \\ MScMarineMeasure
}

\begin{abstract}
AUTHORS
Christian Winter, Marius Becker, Knut Krämer, Gianna Persichini, Gabriel Herbst, Giuliana Silva Mendoza, Arne Knies
\end{abstract}

Chief Scientist:

Prof. C. Winter, Coastal Geology and Sedimentology, Institute of Geosciences University, Kiel, Germany 


\section{Table of contents}

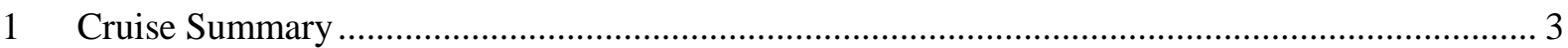

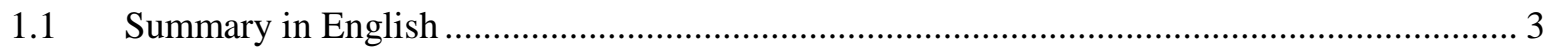

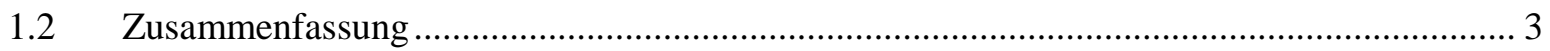

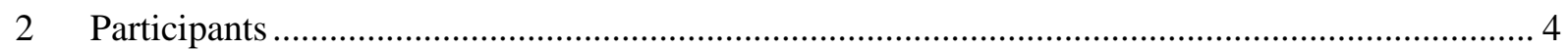

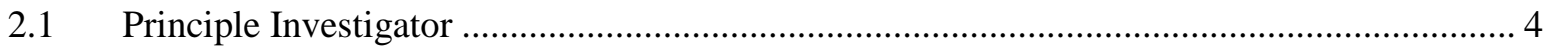

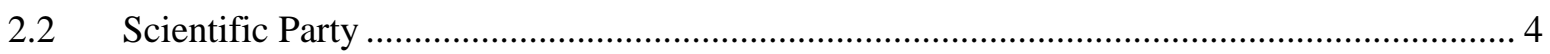

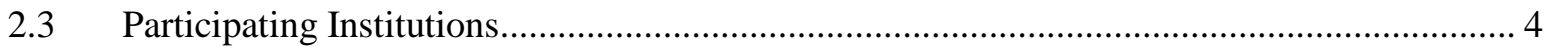

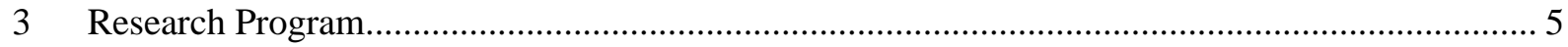

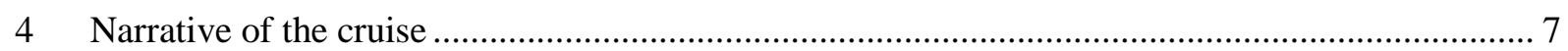

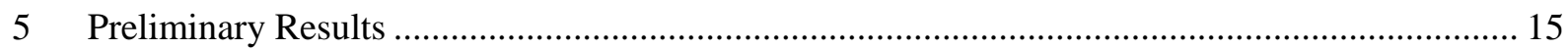

5.1 Fehmarn Belt summer stratification - evidence for seasonally different flow regimes ......... 15

5.2 Human Impact on the Seafloor of the Mecklenburg Bight ................................................... 16

5.3 Postglacial Sea Level fluctuations in the Mecklenburg Bay - reconstructing paleo environments by sediment cores andshallow seismics................................................................ 17

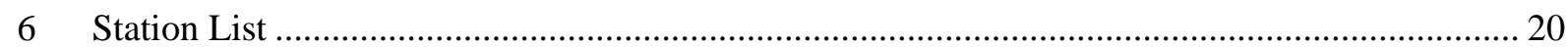

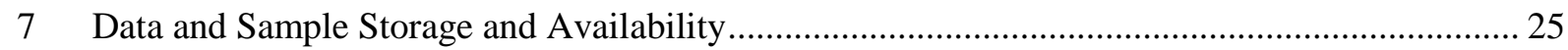

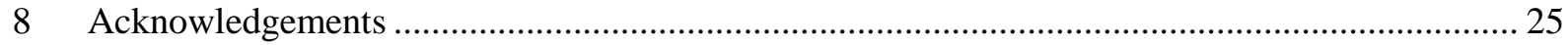




\section{Cruise Summary}

\subsection{Summary in English}

Cruise AL552 had been applied for and planned as a teaching course for students of the MSc Marine Geosciences at Christian-Albrechts-Universität Kiel for hands-on experience on standard marine geoscientific instrumentation from Kiel to the Kiel and Mecklenburg Bay, Western Baltic Sea.

Following regulations concerning the COVID19 pandemic, no field courses for students of CAU were allowed during this time. Anyway, the cruise was carried out with a group of scientists of the Institute of Geosciences CAU Kiel and scientific data was generated for later teaching of the students and research.

The research program was on water column measurements and sedimentological observations of the seafloor and subseafloor structures. Work areas were located North and East of Fehmarn Island, in Mecklenburg Bay, and Kiel Bay. 135 CTD profiles (density, oxygen) were taken. ADCP measurements (velocities) were taken seven cross-sections. 11 larger areas were mapped with Multi Beam Echo Sounder, Sidescan Sonar and Sediment Echo Sounder. 71 Grab samples and 3 gravity cores were taken.

\subsection{Zusammenfassung}

Die Ausfahrt AL552 war als Geländeübung für Studenten des MSc Marine Geosciences an der Christian-Albrechts-Universität Kiel geplant, um praktische Erfahrungen in Methoden der marinen Geologie zu vermitteln. Wegen der Bestimmungen zur COVID19-Pandemie waren keine Feldkurse mit aktiver Teilnahme von CAU-Studierenden möglich. Dennoch wurde die Reise mit einer Gruppe von Wissenschaftlern des Instituts für Geowissenschaften CAU Kiel durchgeführt, um Daten und Lehrmaterial für den Unterricht zu erstellen.

Das Forschungsprogramm befasste sich mit Messungen in der Wassersäule und sedimentologischen Beobachtungen von Strukturen am Meeresboden- und im Untergrund. Untersuchungsgebiete befanden sich nördlich und östlich der Insel Fehmarn in der Mecklenburger Bucht und in der Kieler Bucht. CTD-Profile (Dichte,) und ADCP-Messungen (Geschwindigkeiten) wurden an zwei Querschnitten durchgeführt. 11 größere Bereiche wurden mit Fächerecholot MBES und parametrischen Echolot SES kartiert. Greiferproben, 2 Kastengreifer und 3 Schwerelotkerne wurden entnommen. 


\section{Participants}

\subsection{Principle Investigator}

\begin{tabular}{llc}
\hline Name & Discipline & Institution \\
\hline Prof. Dr. Winter, Christian. & Geosciences & CAU
\end{tabular}

\subsection{Scientific Party}

\begin{tabular}{lll}
\hline Name & Discipline & Institution \\
\hline Dr. Becker, Marius & Geosciences & CAU \\
Dr. Krämer, Knut & Geosciences & CAU \\
Persichini, Gianna & Geosciences & CAU \\
Herbst, Gabriel & Geosciences & CAU \\
Silva Mendoza, Giuliana & Geosciences & CAU \\
Knies, Arne & Geosciences & CAU
\end{tabular}

\subsection{Participating Institutions}

CAU Christian-Albrechts-Universität zu Kiel 


\section{Research Program}

The aims of this short cruise were threefold: To teach marine geoscientific methodology and operations (derive data and video images); to test procedures and the combination of different hydroacoustic instrumentation, and to derive data on the hydrodynamics and sedimentology of different sites in the Western Baltic Sea.

The number of stations and different working areas reflect these different targets. The cruise visited different work areas. All working areas are located in the Western Baltic Sea. They are indicated in Figure 3.1. In detail the following areas were visited:

- Fehmarn North Dune field: A well-known location for the study of the morphology and sedimentology of subaquatic compound dunes was revisited and mapped with Multibeam Echo Sounder (MBES) and sediment echo sounder (SES). Grab samples for sedimentary analyses were taken along two bedforms.

- Fehmarn Link: The site of the future tunnel between Denmark and Germany was mapped with MBES and SES for high resolution bathymetry and subbottom structures.

- Fehmarn Belt East bedforms: For a continued study of small sea floor structures MBES and SES mapping was carried out, grab samples were taken, and one sediment core was taken by gravity coring.

- Fehmarn Belt transects: Several N-S transects (German waters only) across the Fehmarn Belt were sailed to measure stratification of the water column and possibly an exchange flow situation into and out of the Baltic Sea. ADCP velocities and CTD densitiy profiles were derived.

- Mecklenburg Bay transect: To measure the stratification of the water column an ADCP velocity transect and CTD profiles were carried out across the Mecklenburg Bay.

- Human Impact study sites: Eight different sites were visited around Fehmarn to explore seafloor structures that indicate human impact by MBES, SES, Sidescan Sonar (partly), Vido Cameras (partly)

- Paleochannel Øjet: An area was mapped by MBES to visualise a meandering paleo river valley in the Fehmarn West area.

Investigations were based on different techniques. The following methodology was used:

- A Multibeam Echo Sounder (Norbit STX) was installed in the moonpool of the ship

- A $600 \mathrm{kHz}$ RDI ADCP was installed in the moonpool of the ship

- A USBL underwater positioning system was installed in the moonpool of the ship for precise location of grab samples 
- A handheld Sea\&Sun CTD 48M was used for water column Temperature and Conductivity measurements, also to calculate sound speed for the correction of MBES data.

- For bed surface sampling a Van Veen sediment grab and a shipek sediment sampler were used. These were combined with UBL positioning.

- A gravity corer was used, both with plastic foil liner for quick analysis and photography (for teaching) and with regular plastic liners, which were cut into $1 \mathrm{~m}$ sections on board.

- A SideScan Sonar device was used from the A-frame on stern of the ship.

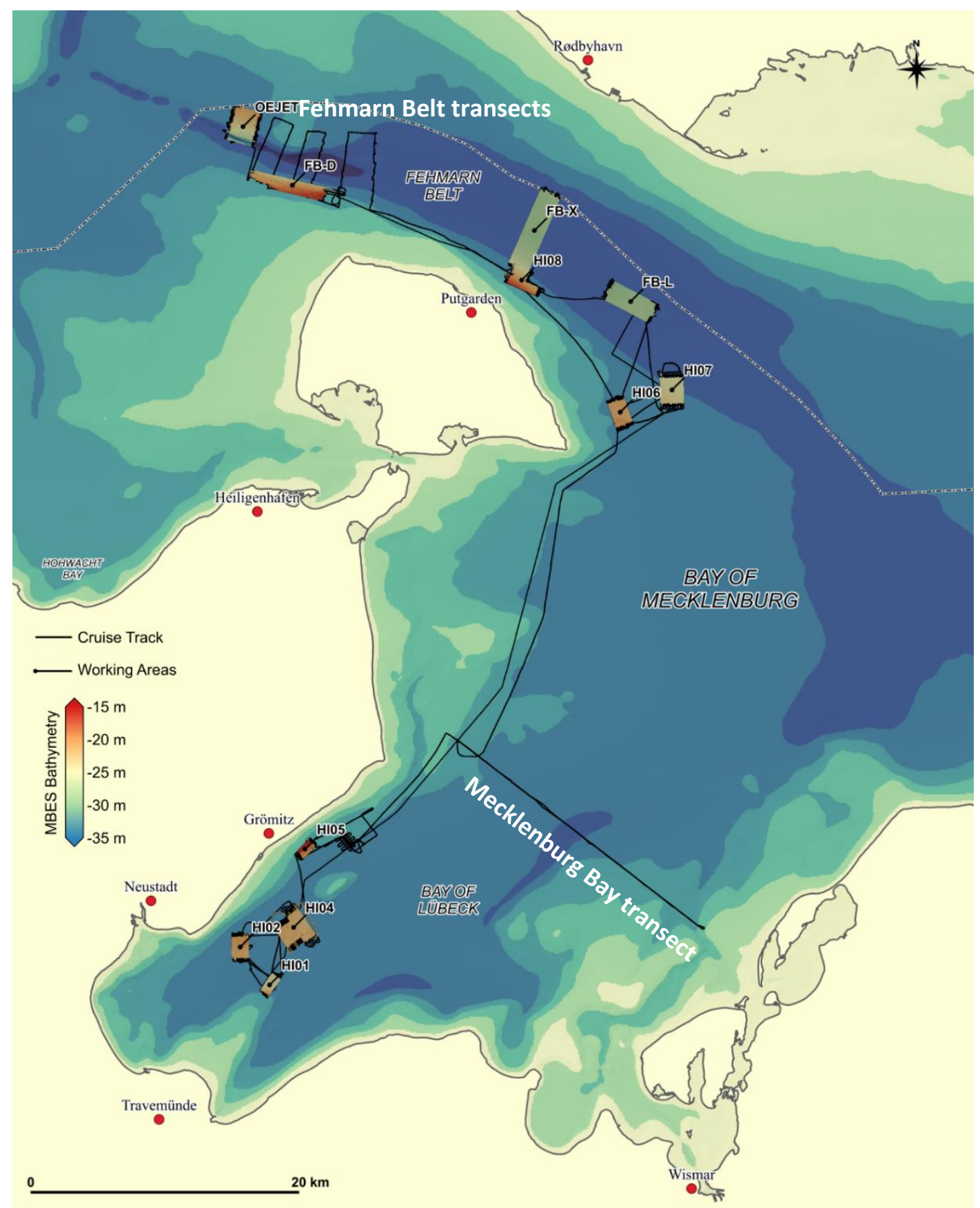

Figure 3.1: $\quad$ Track chart of AL552. Eleven main working areas and transects are indicated. 


\section{$4 \quad$ Narrative of the cruise}

On day 1 (Tue 16.03.2020) we left Ostufer pier at 8:00 for a 4.5 hour transit to Fehmarn Belt dune field. After a CTD Profile for sound speed we started mapping the Fehmarn North dune field (FBD): Simultaneously Multi Beam Echo Sounder (MBES), ADCP, and the hull mounted parametric echo sounder Innomar SES 2000 was used to map a bedform field from about 15 to $25 \mathrm{~m}$ water depth. The compound dune pattern is a prominent example for large dune patterns in micro tidal environments. This has been mapped several times during other teaching cruises so a time series of dune characteristics could be established. In the course of the mapping the MBES system was calibrated and frequent CTD profiles (handheld) for the updating of sound velocity. The mapping was carried on over night.

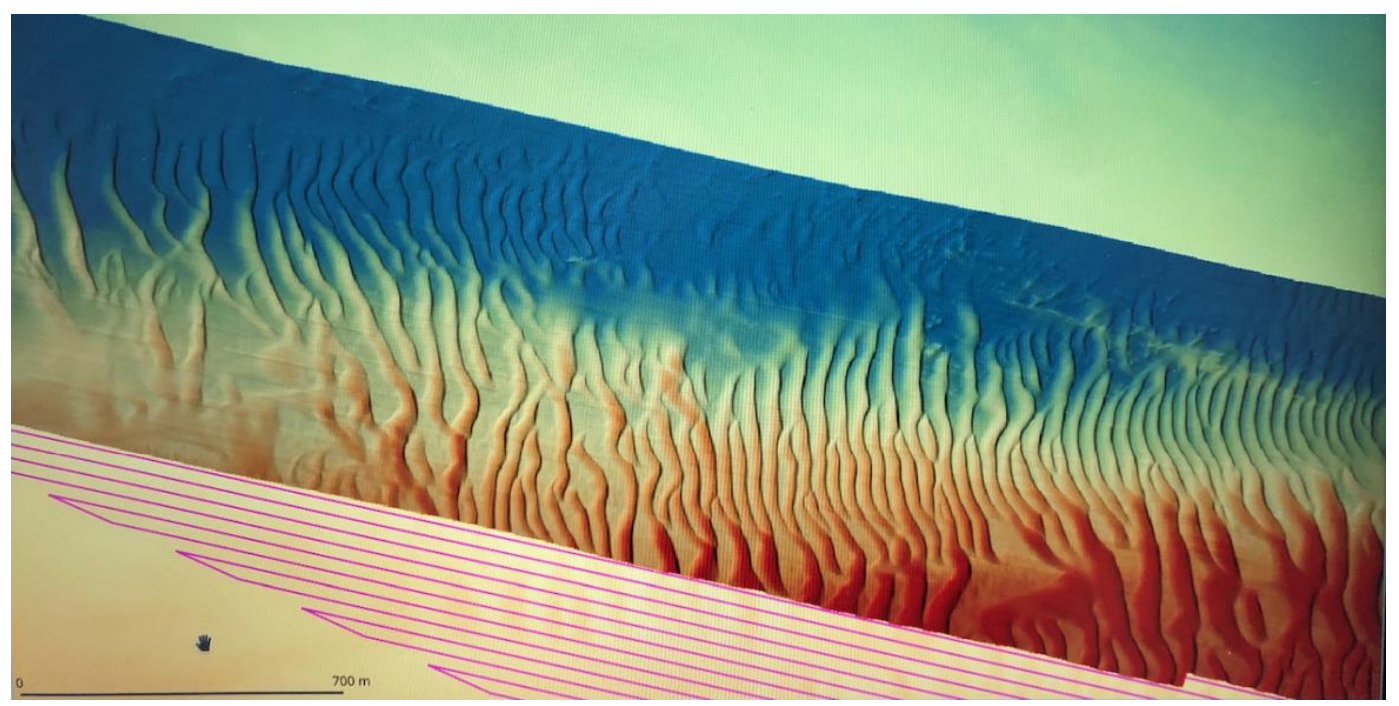

Figure 4.1 Fehman Belt dune field (FB-D)

On day 2 (17.3.2021) until noon the mapping of FB-D was continued, frequent CTD profiles for the updating of sound velocity were taken. A USBL system then was installed and tested for exact location of grab samples. This worked well and from 13:00 17 exactly positioned Shipek bed surface grab samples were taken along a bedform crest and trough, and a bifurcation of these. After this we proceeded to the Fehmarn LINK cross-section (FB-X) for a MBES, SES, ADCP mapping of this area following a N-S pattern. At the northern ends of the profiles CTD profiles were taken. The mapping started at 20.00 and lasted throughout the next day 3 (18.3., 19:13). After a short transect further east we arrived at a field of small bedforms (FB-L) which was mapped by MBES and SES. CTD profiles (handheld) for the updating of sound velocity were carried out after every second transect. 


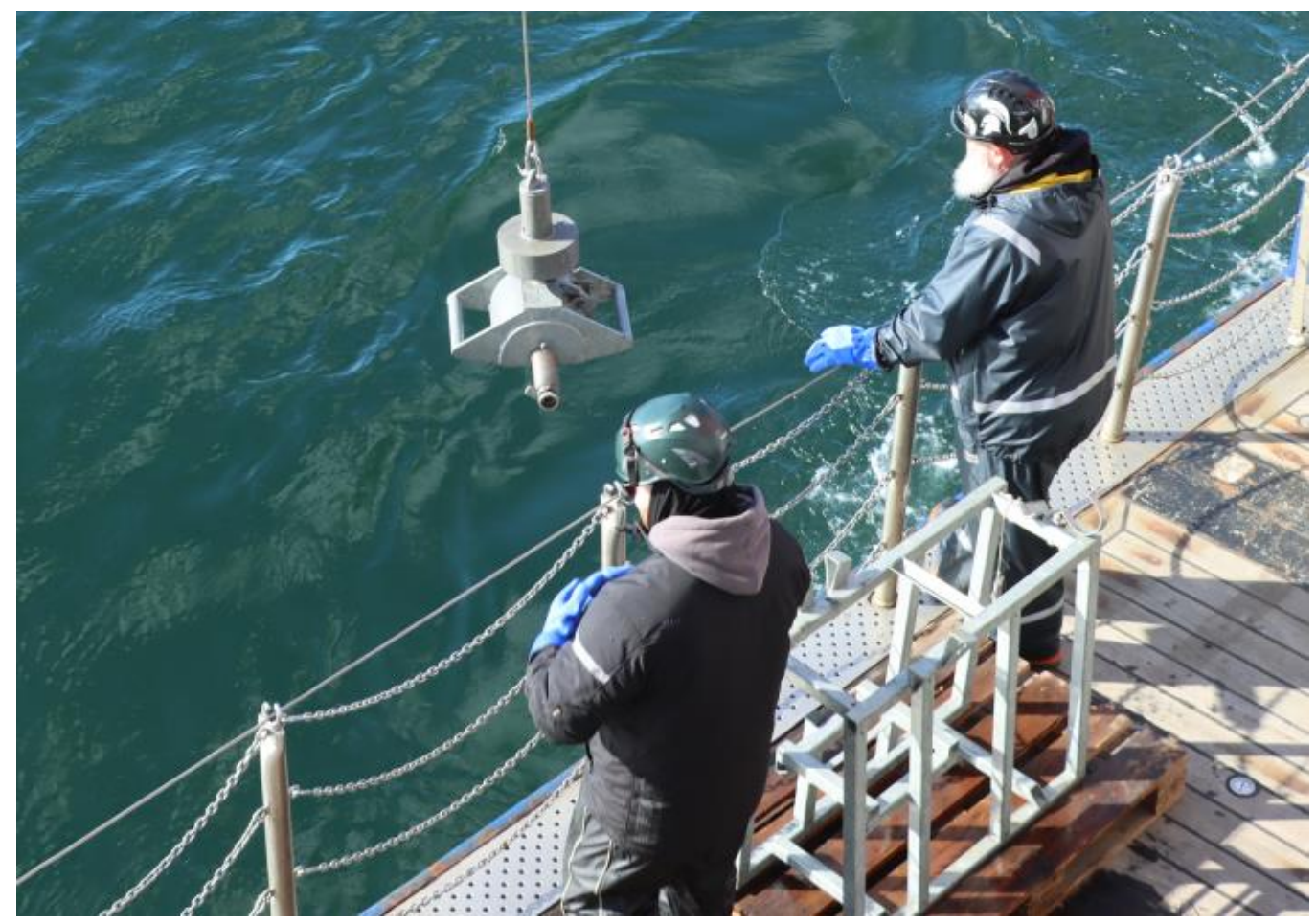

Figure 4.2 Shipek grab sampling

On day 4 (19.3.) Two of the bedforms were measured again with SES in slow vessel speed along and across their crest. Then 18 Van Veen grab samples across and along the two bedforms were well positioned with USBL to describe the sedimentology of bedforms. Later in the cruise (23.3.) three gravity cores were placed into the crest of the bedforms. After noon we proceeded into the Mecklenburg Bay (underway MBES featured two wrecks) to start a series of observations of different seafloor areas which show prominent features of Human Impact. These areas are numbered HI-1, HI2, etc. and indicated in Figure 3.1. MBES and SES mapping of HI-1 and HI-2 was started after a CTD profile (handheld) for the updating of sound velocities at 21:45 and carried out throughout the night. 


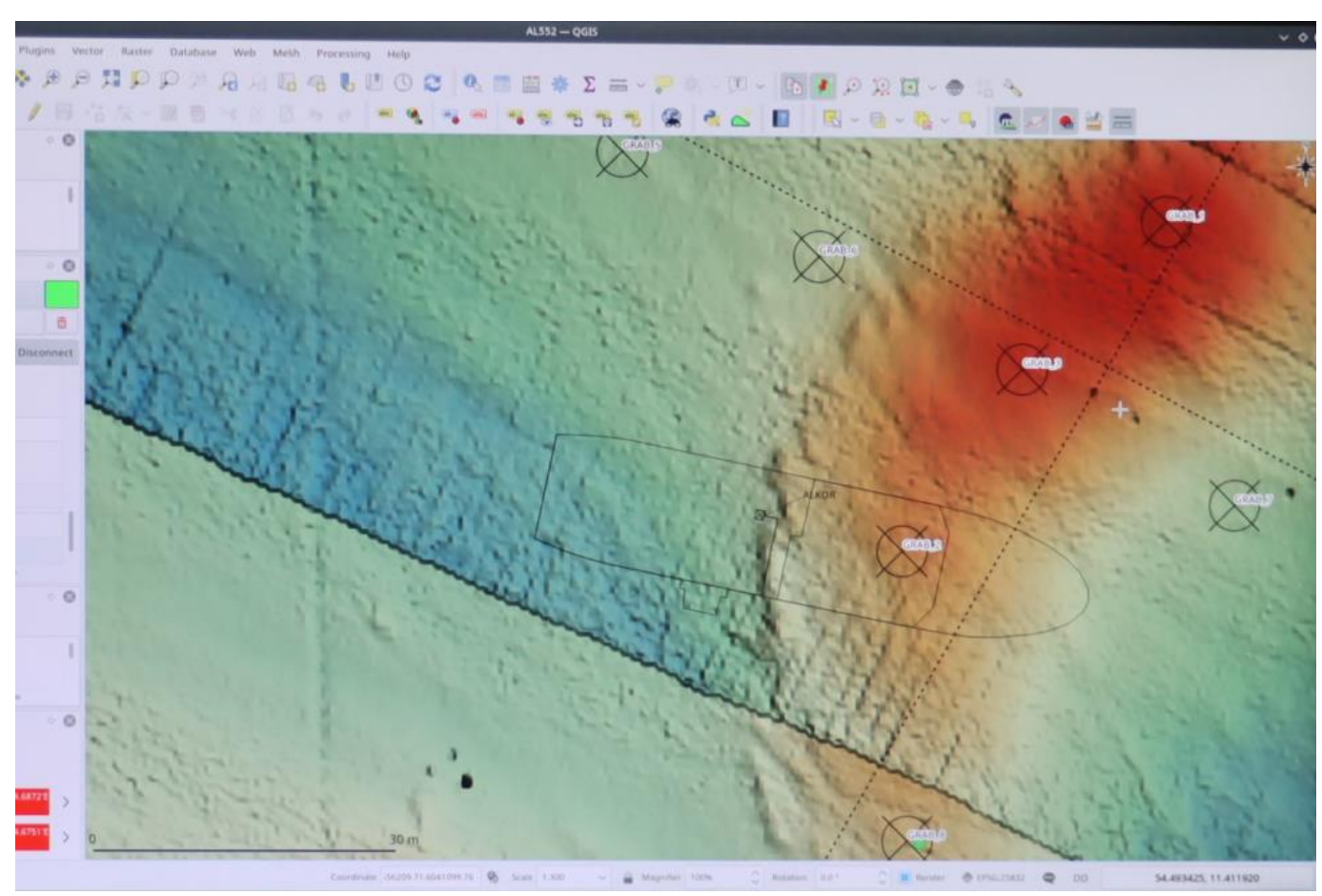

Figure 4.3 Positions of grab samples on the bedform (red feature)

On day 5 (20.3.2021) after completing the mapping of HI-2, at 10:40 UW camera tests (light configurations) were carried out and 3 video profiles of the seafloor were filmed. The transit to Mecklenburg Bay Human Impact Area HI-3 was short and at 17:00 the mapping with MBES and Sidescan Sonar could be started. The mapping of HI-3 and later HI-4 continued until the morning of day 6 (21.3.2021). After breakfast USBL positioned high precision 20 Shipek grab samples were taken at relevant positions of the human impact areas. After lunch two Video transects were performed in this area together with MBES recording. Later (17:14) mapping of HI-4 was continued, followed by transit to Mecklenburg Bay Human Impact Area HI-5. The mapping of HI-5 was carried out from 20:00 until 1:00 of the next day. 


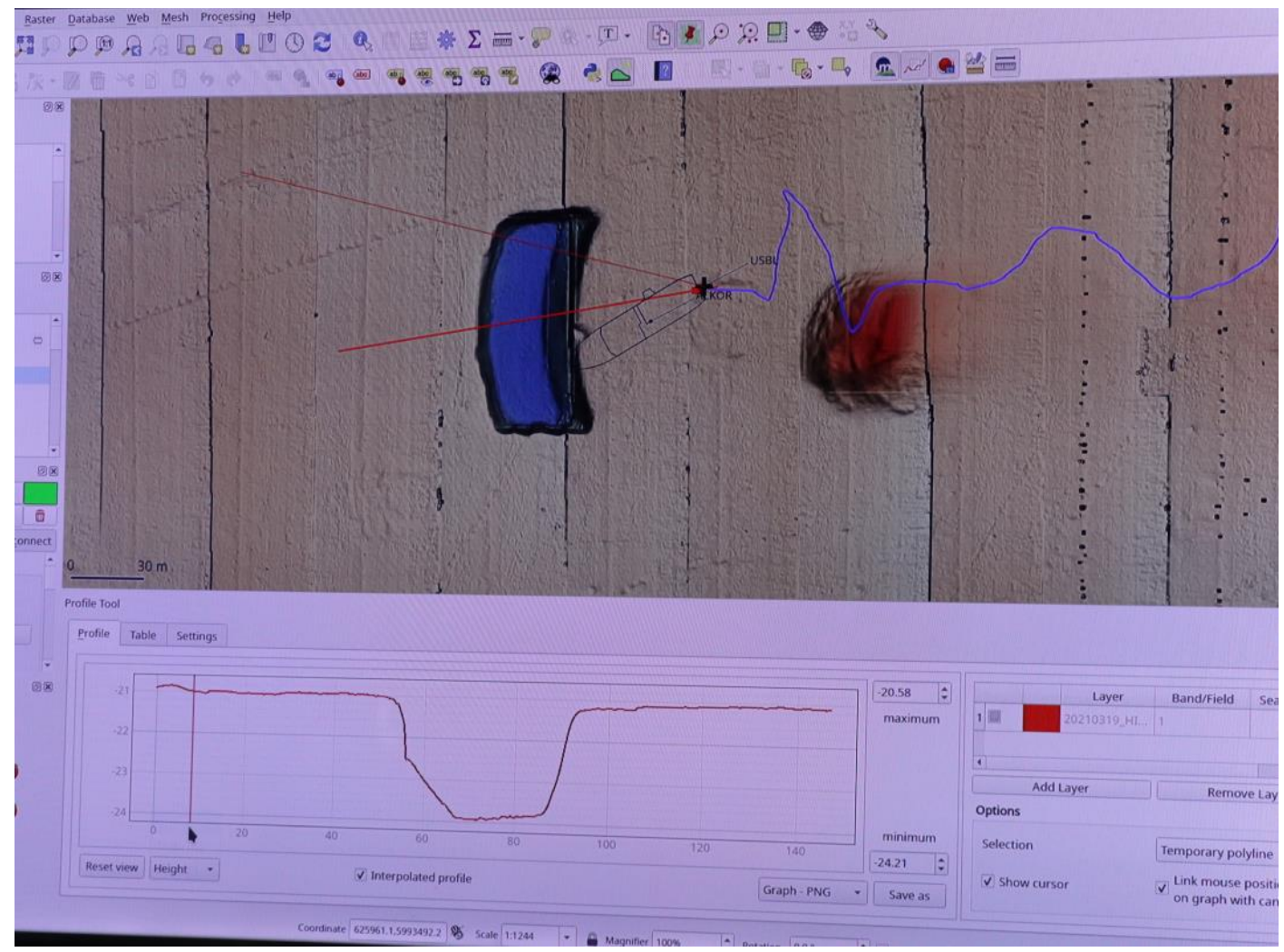

Figure 4.4 Camera profiles across different feaztures on the seabed

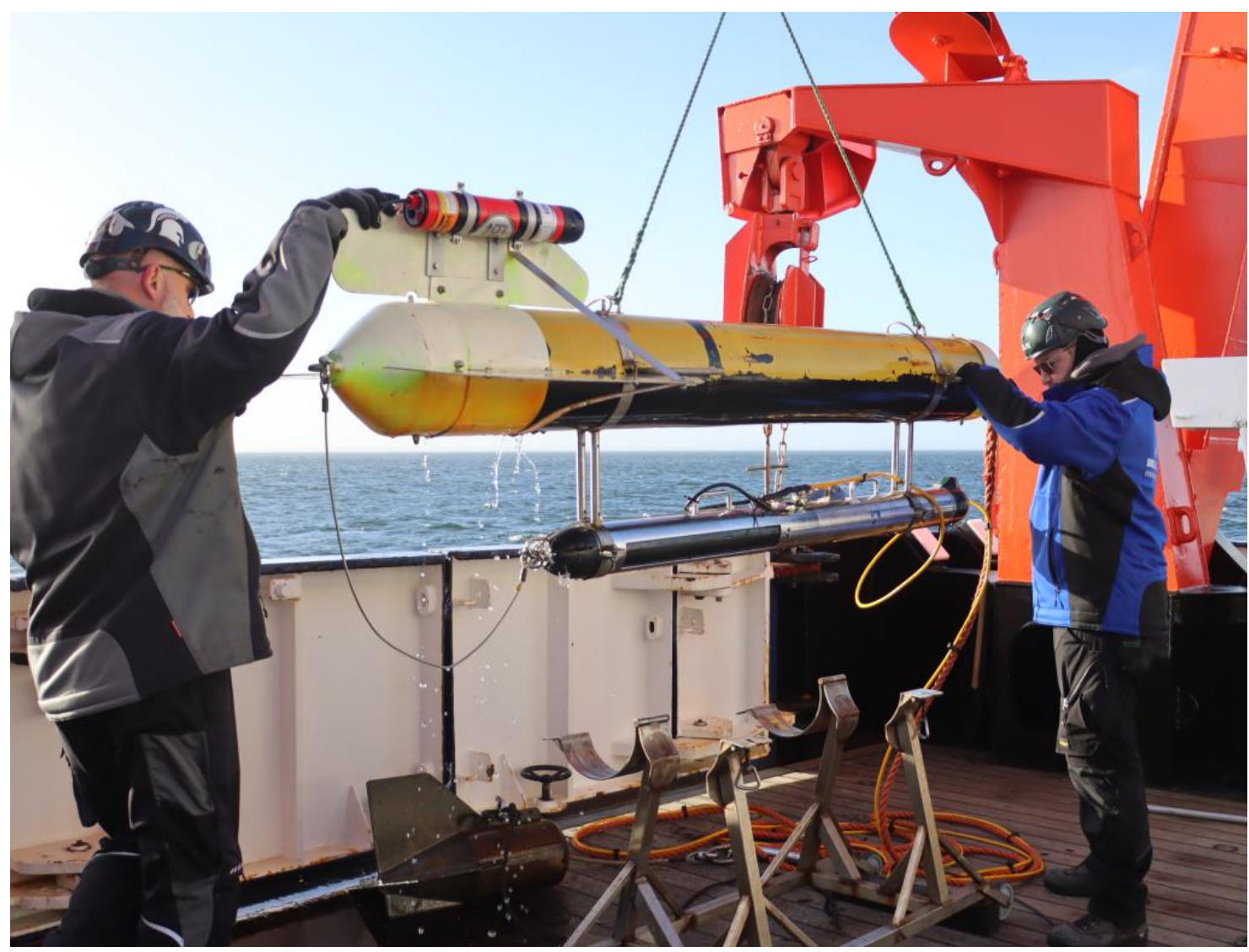

Figure 4.5 Sidescan Sonar after deployment 
On day 7 (22.3.2021) we started early with dedicated MBES / SES transects to determine a good position for a gravity core (GC1) for teaching the post-glacial evolution of Mecklenburg Bay. At Mecklenburger Bay, Kellenhusen core location a former (student) cruise had revealed interesting core material and it was decided to recover a core for lab analysis. In order to provide photographic footage on different sampling strategies with the gravity corer, foil liner cores were taken at that location. The coring went well and the initial description revealed similar characteristics as expected. Three positions were chosen, 4 Gravity cores taken and photographed (130_1, 130_2, 131, 132), only one 130_2 was taken back onshore for further analyses in the lab by the students. To derive further examples for the stratification and circulation of the Batltic Sea, another cross- section of first CTD profiles and continuous ADCP profiling on the way back was carried out across Mecklenburg Bay cross-section towards the east, and back with 12 CTD casts (134-145). The night was spent in mapping another small human impact site, i.e. HI-6 and HI-7 (146) with SES and MBES. 


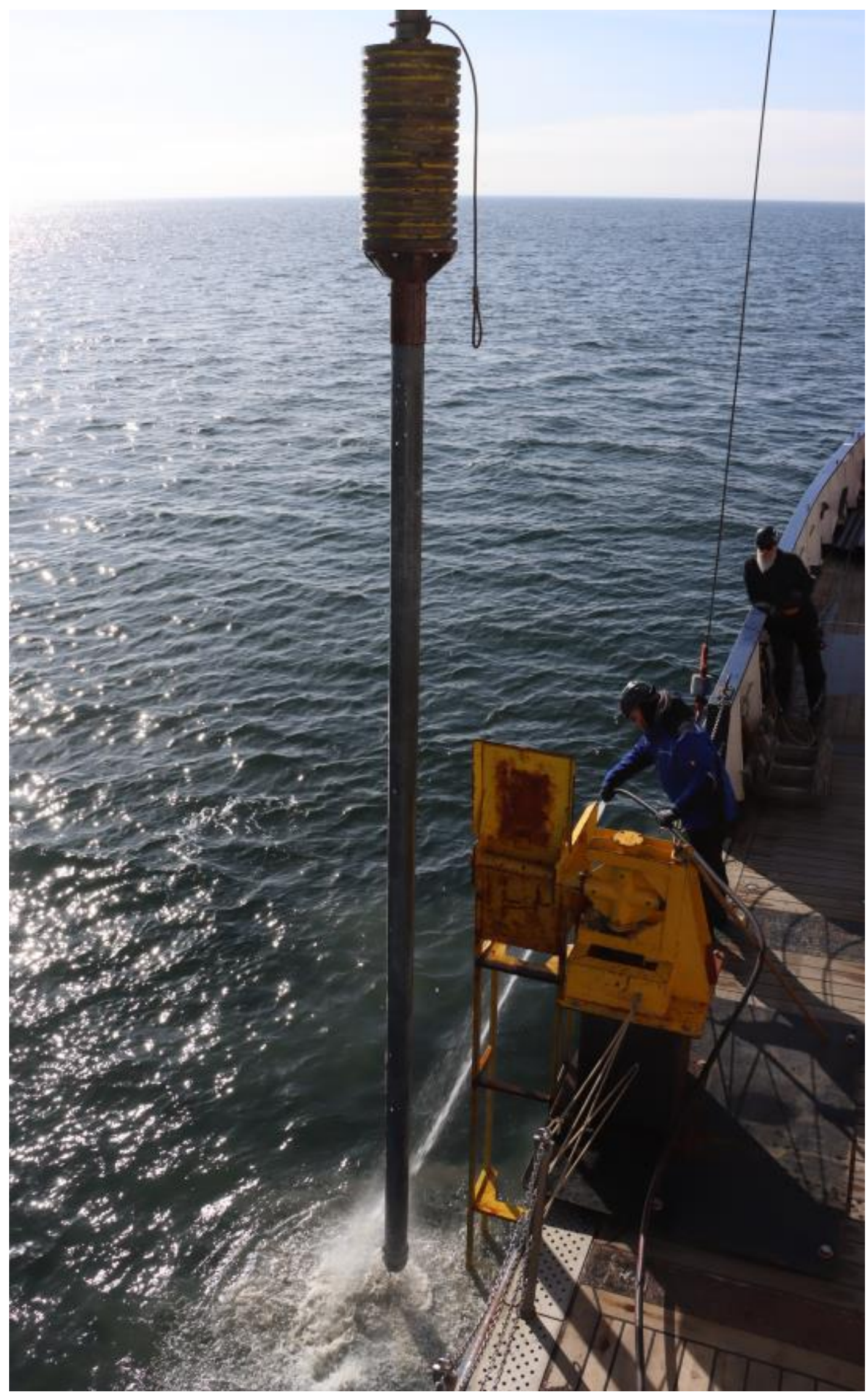

Figure 4.6 Gravity corer (5m) 


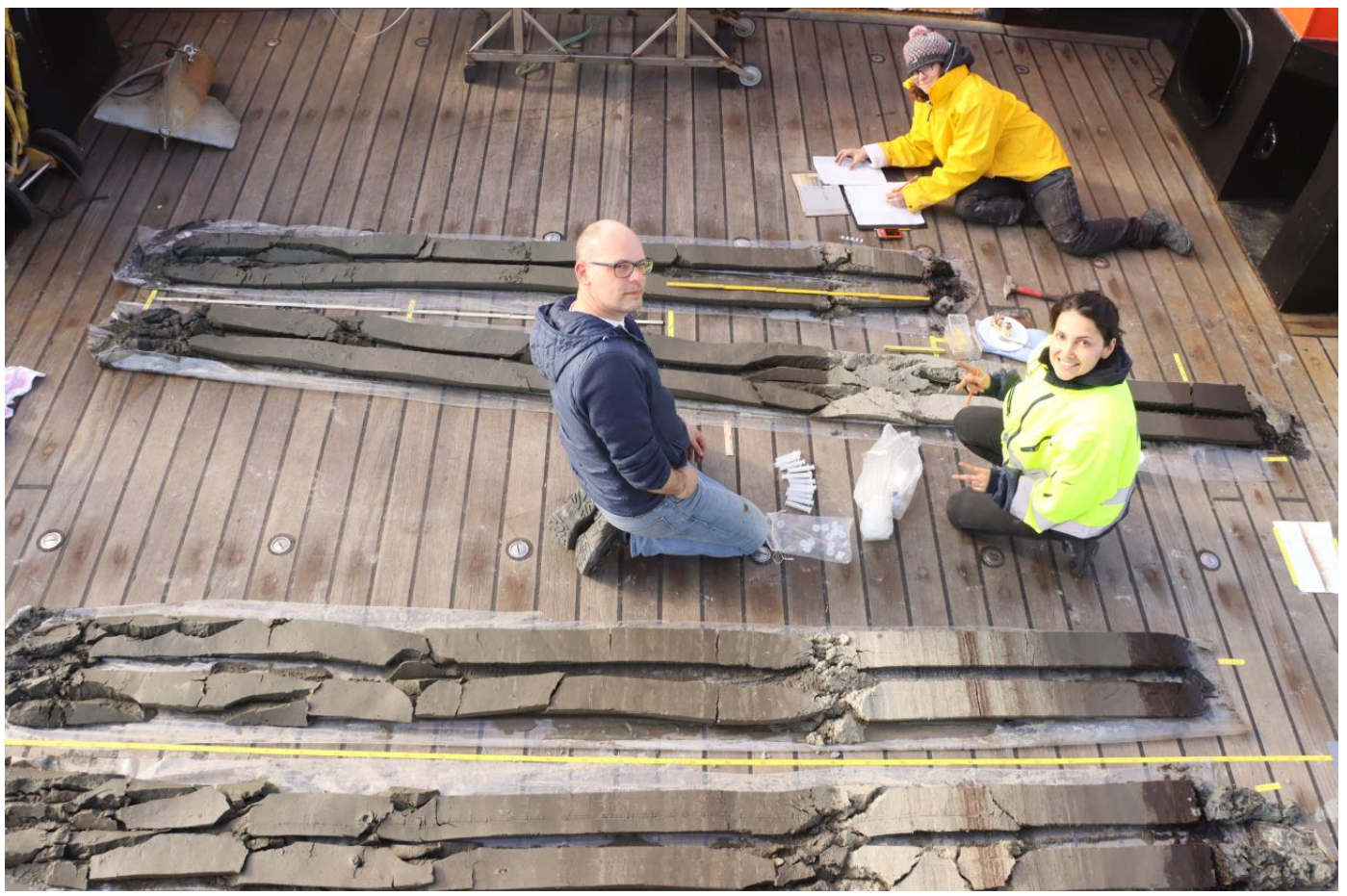

Figure 4.7 Initial description and sampling of student cores

In the morning of day 8 (23.3.2021) we went back to the field of small bedforms (FB-L) to finally drive three gravity cores into the crests. Based on the earlier measured MBES maps and SES subbottom profiles, the exact locations could be found and three gravity cores were placed $(147,148$, 150). All of which were sampled in plastic liners, cut in half, and initially described on the ship. We continued at this location with two video transects across the bedforms. The sharp crest of a bedform is visible, also remnants of the gravity corer and boxcorer positions of a previous cruise.

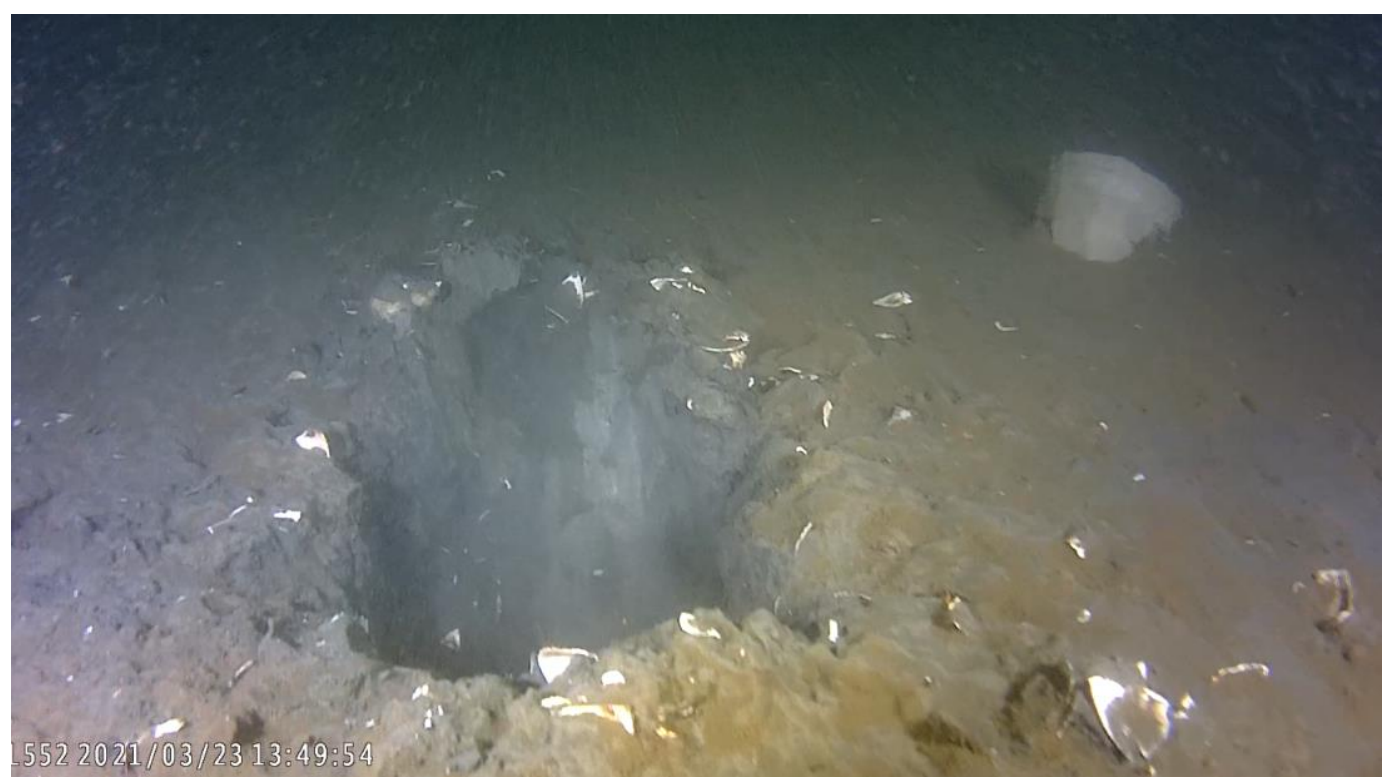

Figure 4.8 Gravity corer hole seen in video profile after sampling 
After the video profiles we proceeded to area HI-7, a small dumping ground east of Fehmarn. Here mapping with SSS, MBES, ADCP was carried out from 15:55 until 3:00 the next morning. The side scan sonar had to be taken out at about 22.:00 for technical reasons but the MBES.

On day 9 (24.3.2021) after breakfast video profiles were taken across the dumping field across features detected in the MBES recordings. At 10:00 we moved back to area HI-6 for three camera profiles and seven grab samples. In the afternoon we went to HI-8 (Fehmarn link south) for additional mapping with MBES, SES. After a CTD profile (handheld) for the updating of sound velocities the mapping was carried out from 16:10 until 3:03 in the next morning (171).

On day 10 (25.3.2021) 6 SHIPEK grab samples were taken in HI-08, far away from a cable on the seafloor. Also two video profiles were taken together with MBES mapping to survey structures on this human impact area. The rest of the day was spent on a series of ADCP and CTD cross-sections carried out in S-N and N-S directions. Six cross-sections of water column properties were measured, with 59 CTD casts along the way. These transects ended before midnight in the vicinity of Ojet, a shallow area on the northern side of the Fehmarn Belt.

Day 10 (26.3.2021) started at midnight with a high resolution MBES and SES mapping of a channel system west of Ojet until 11:25. This channel features a meander which was additionally mapped by eight SES profiles across the channel and one SES profile along the thalweg of the creek. The last scientific activity of the cruise were two additional camera profiles across different ridges at Ojet. We then returned to Kiel Westufer and were at 20:30 at the pier.

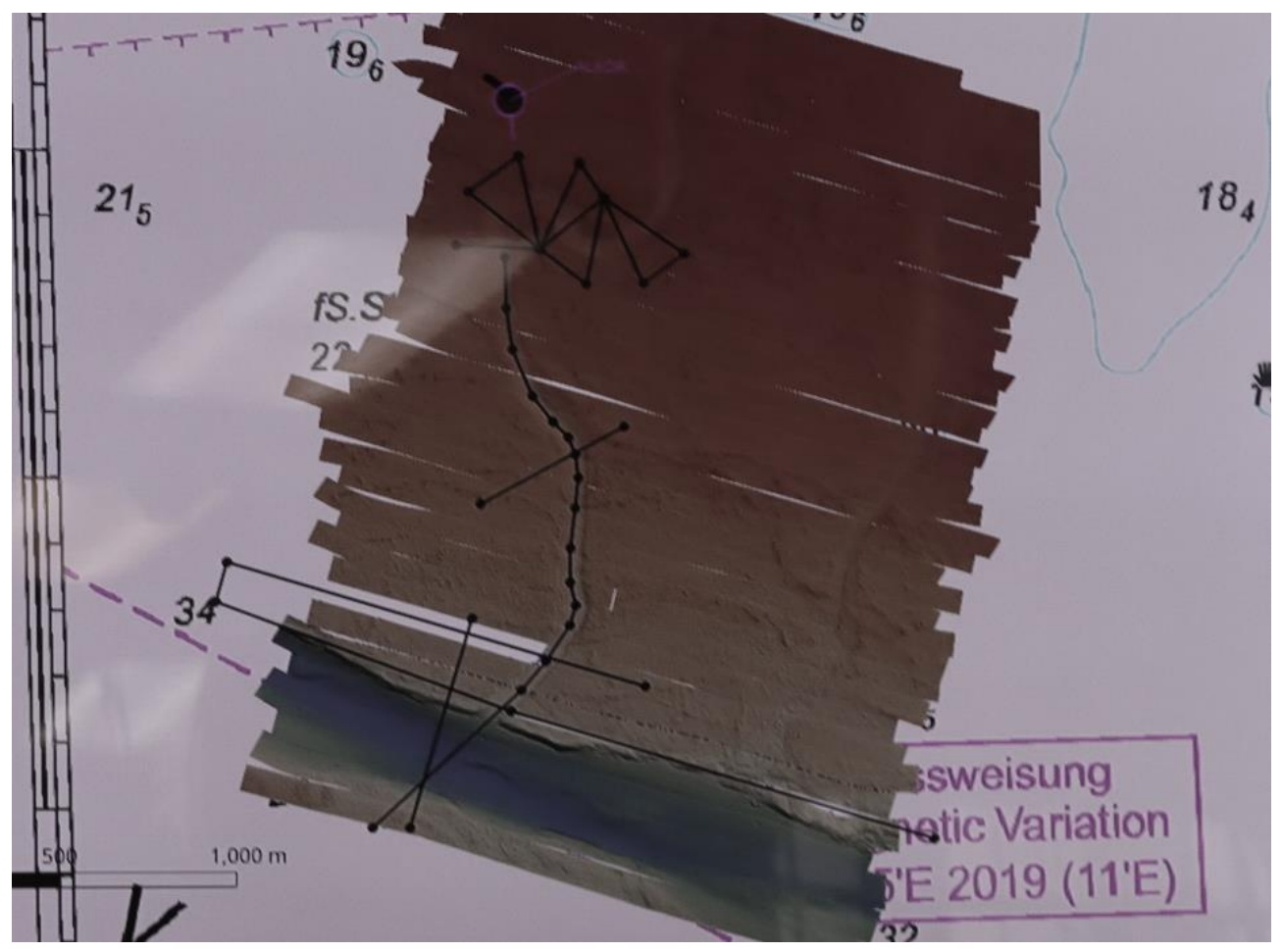

Figure 4.9 Meander channel in Fehmarn Belt area as mapped by MBES 


\section{Preliminary Results}

This cruise provided interesting data on the hydrodynamics and sedimentology of the research areas, video footage for teaching marine geosciences classes, and also this cruise provided opportunities to develop and test new technical set-up and procedures (e.g. in exact positioning of cores and grab samples).

Preliminary results were put into format by students of the Master course. Their task was to write a scientific essay on preliminary results of the cruise AL552. Here examples of abstracts are given.

\subsection{Fehmarn Belt summer stratification - evidence for seasonally different flow regimes}

(Peter Matzerath, Elisaveta Sokolkova, and and Shipboard Scientific Party)

Two different data sets of stratigraphical and flow regime investigations in the Fehmarn Belt are presented. In this study we compare data from CTD and ADCP profiles in the Fehmarn Belt from two RV Alkor cruises (AL523/1 and AL552) that took place respectively in June 2019 and March 2021, representing summer and spring stratification and flow patterns for this region (Figure 5.1).

The focus of this study was to increase evidence about seasonal stratification and flow differences in one of the straits that characterizes the North Sea - Baltic Sea transition zone. The data shows that during summer, a strong stratification in the strait region is present, whereas in spring the water is well mixed. Additionally, the flow regime is different between the two seasons. In summer, the flow of deeper waters is directed towards the Baltic Sea while the surface and intermediate layers show a flow towards the North Sea. Inflowing saline waters in the deepest layers in summer further increases the vertical stratification. On the contrary, in spring, a flow towards the Baltic Sea throughout all layers in the profile is visible. This inflow enables ventilation of the Baltic Sea, yet a permanent halocline near the bottom is still present. The data supports current knowledge about seasonal inflow, outflow and stratification patterns of the Baltic Sea and provides more evidence about the stratification and inflow regime of the Fehmarn Belt. 

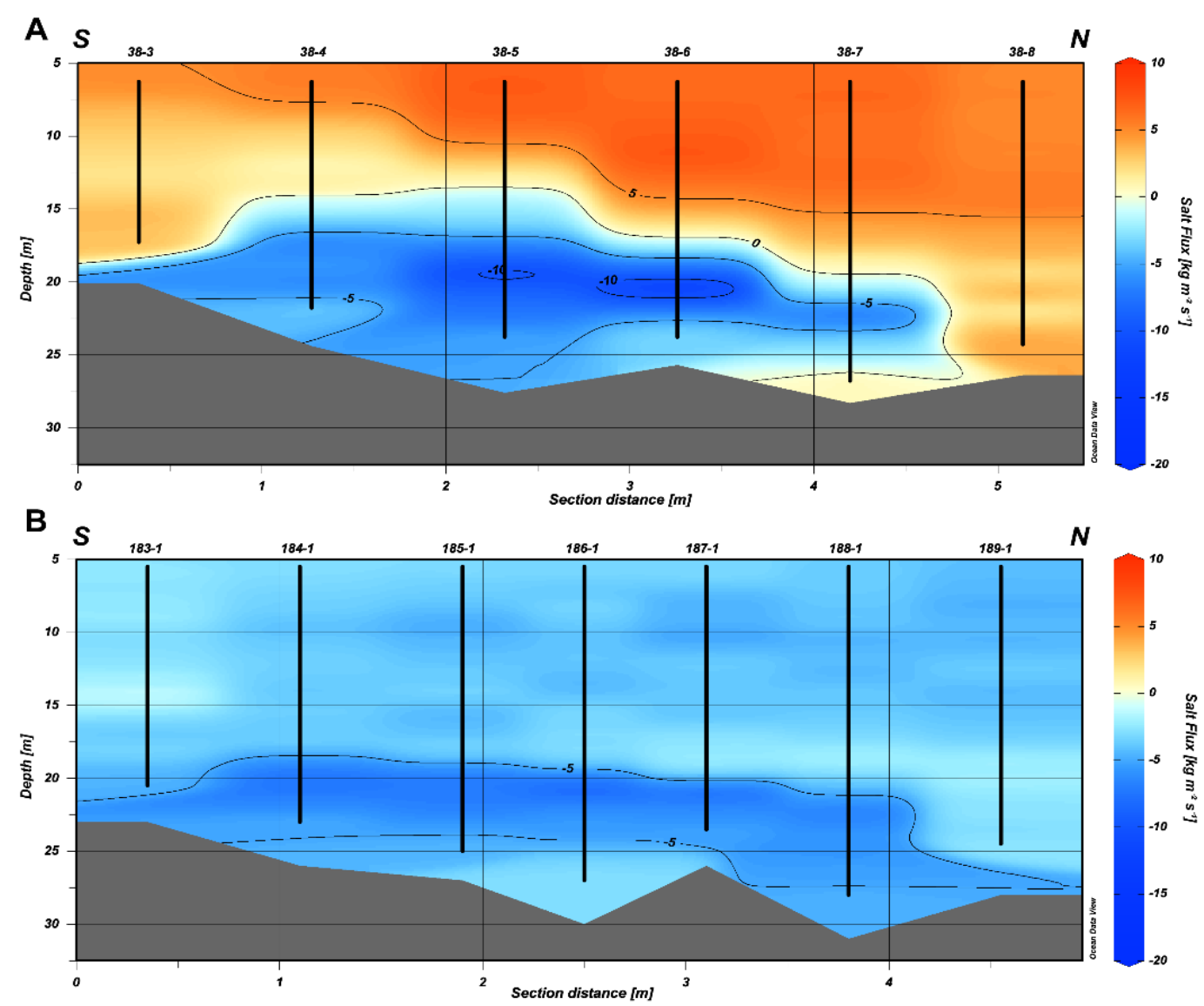

Figure 5.1 Calculated salinity flux plotted as water column cross-sections along track AL523/1 (A) and AL552 (B) in the Fehmarn Belt. Profiles from left to right following a south to north direction. Salinity flux values are given in $\mathrm{kg} \mathrm{m}-2 \mathrm{~s}-1$ as a colour bar range from -20 to $10 \mathrm{~kg} \mathrm{~m}-2 \mathrm{~s}-1$. Black vertical lines give relative location of all chosen CTD stations along track AL523/1 and AL552 with according station numbers (see Table 1). Visualization realized with ODV

\subsection{Human Impact on the Seafloor of the Mecklenburg Bight}

(Florence Gifty Boham, Mathis Degler and , and Shipboard Scientific Party)

The impact of human activities on nature has wide range of effects. The aim of this study focusses on the impact on the seafloor of the Mecklenburg Bight. The area is known for a lot of human activities from sediment and ammunition dumping, commercial (fishing, dumping), to recreational (tourism, water sports). All these activities tend to have effects on seafloor like trawl marks, anchor marks, resuspension and relocation of sediments, depressions, contamination and change of morphology. New data collected on RV ALKOR AL552 expedition include Side Scan Sonar (SSS), Multi-Beam EchoSounding (MBES) and visual observations (video, Figure 5.2). Analyses of the processed data was carried out using QGIS and stills of features in the video data. Objects and structures found were identified as possible trawl marks, anchor marks, dumping spots, dumping sites and dumped ammunition (Figure ). To confirm the findings, further investigation using higher resolution and additional methods like sediment sampling is recommended. 


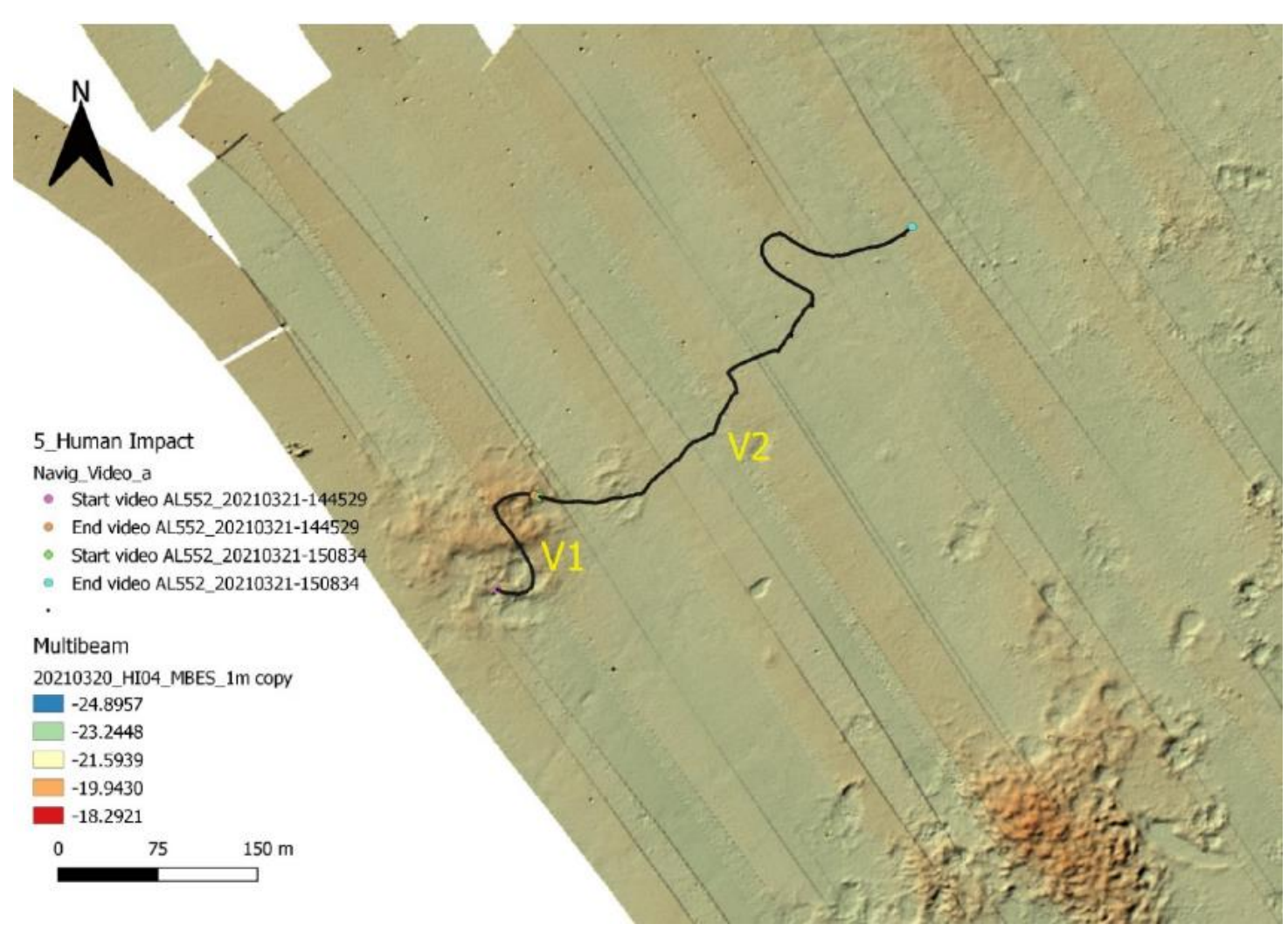

Figure 5.2 Bathymetric map with the track of the video sequences

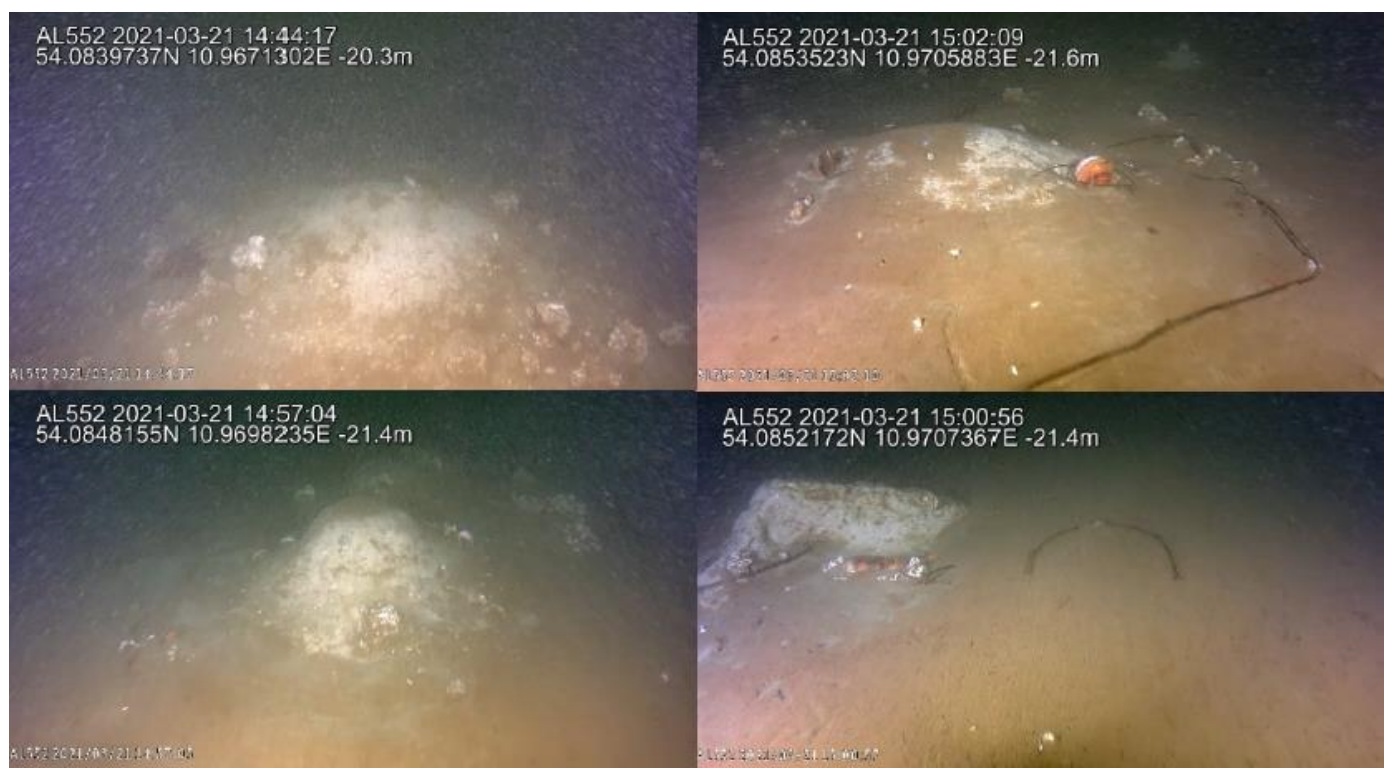

Figure 5.3 Stills of the smooth sediment hills (V1.7, V2.15, V2.9, V2.13 from upper left to lower right) (A1552 2021)

\subsection{Postglacial Sea Level fluctuations in the Mecklenburg Bay - reconstructing paleo} environments by sediment cores and shallow seismics

(Johanna Schenk, Antina Lippert, and Shipboard Scientific Party) 
A sediment core from the Mecklenburg Bay was analyzed and compared with a local seismic profile (Figure ) from the research cruise AL552 in 2021 on the German research vessel Alkor. The data shows indications for links between the sediment described in the core sections and the 4 major phases in the postglacial history of the Baltic Sea. We determined the position of the sediment core in the seismic profile and concluded where and why the different stages and their depositions started and ended in the sediment core (Figure ).

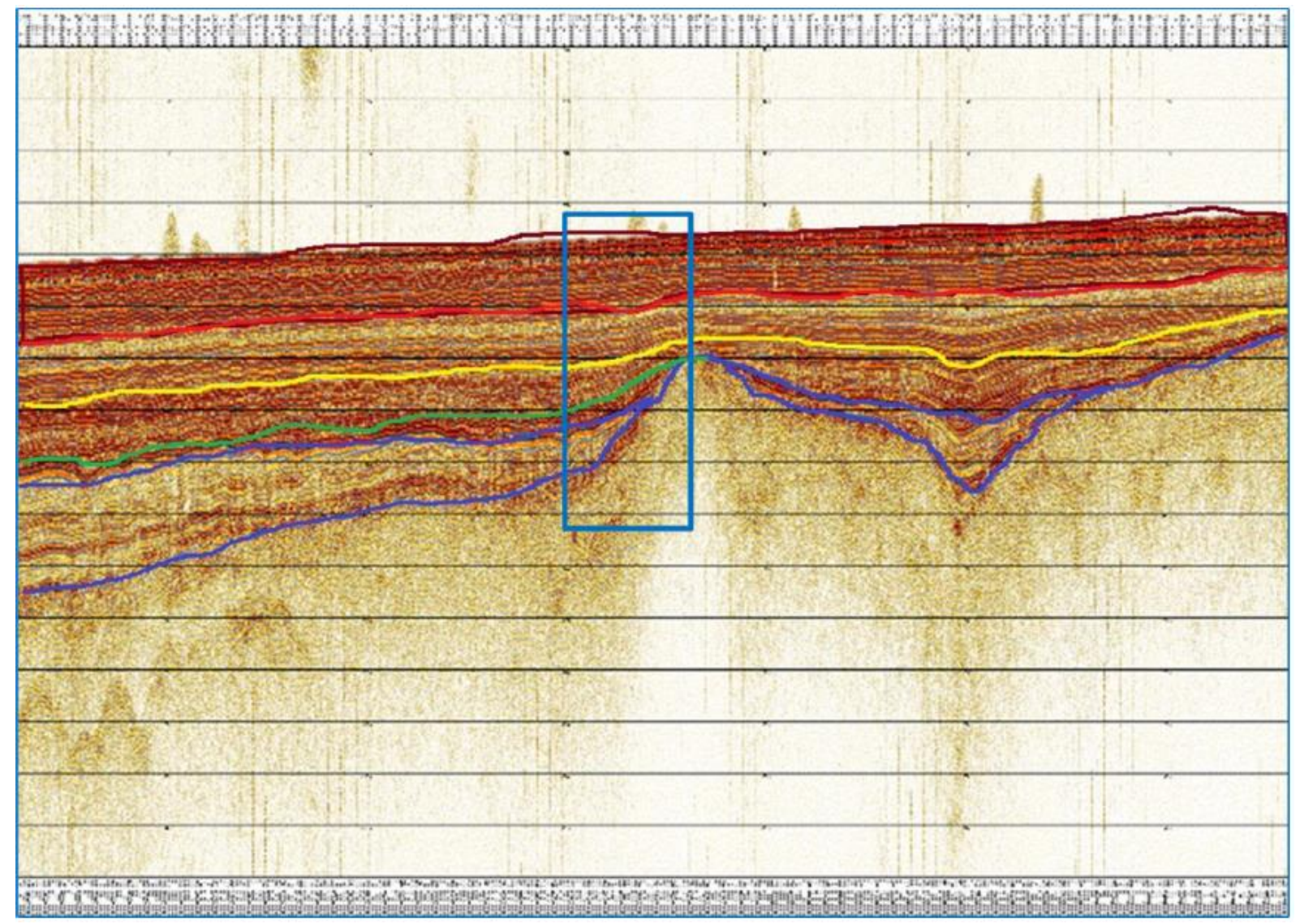

Figure 5.4 Seismic Profile; Blue rectangle: Possible Location of the Sediment Core, Blue lines: Section 1, Below the green line: Section 2, below yellow line: Section 3, below red: Section 4, below brown: Section 5 


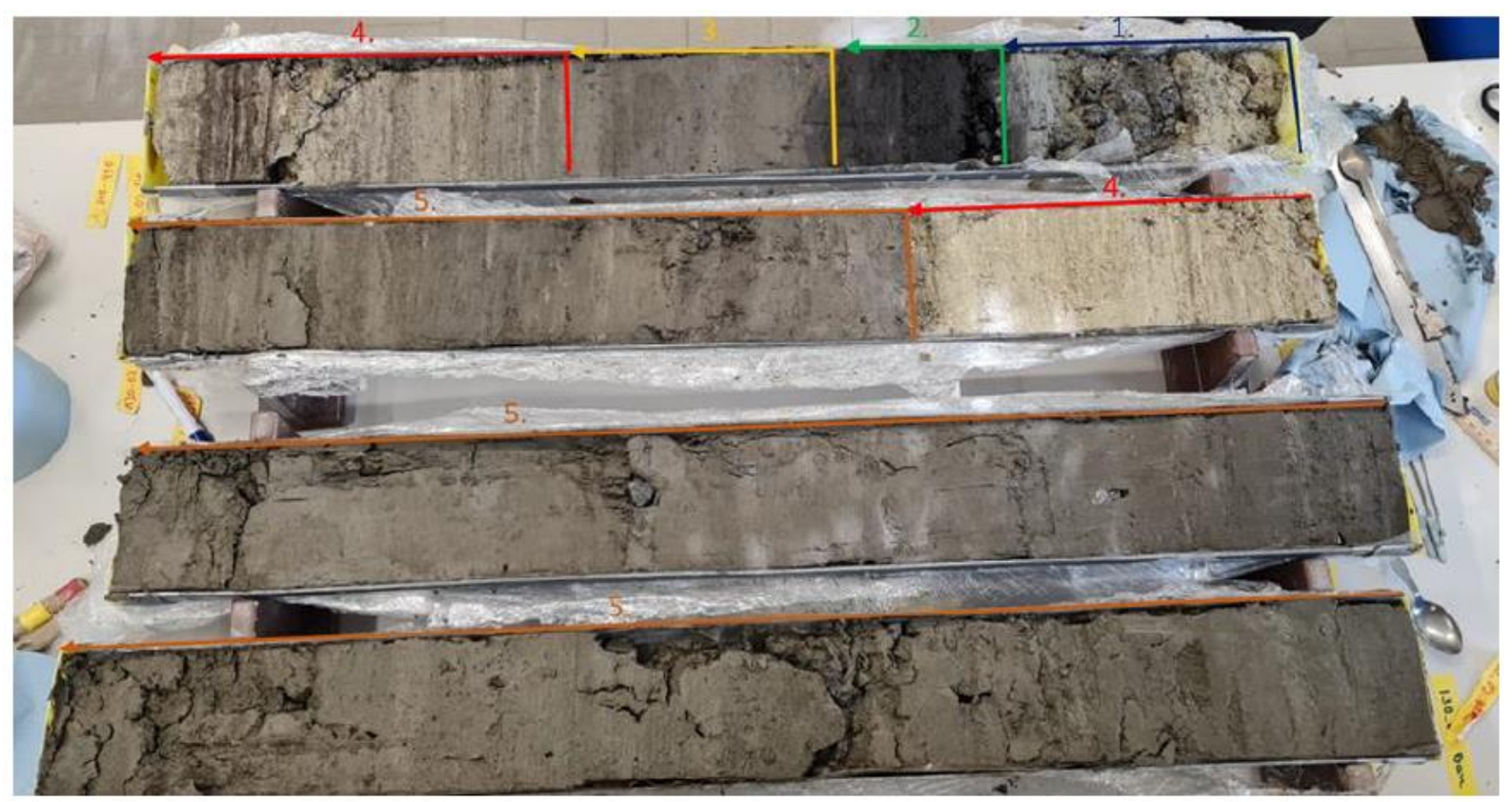

Figure 5.5 Sediment Core; Dark Blue: Section 1, Green: Section 2, Yellow: Section 3, Red: Section 4, Light Blue: Section 5 


\section{Station List}

\begin{tabular}{|c|c|c|c|c|c|c|c|}
\hline Station No. & Date & Time & Gear & Latitude & Longitude & $\begin{array}{l}\text { Water } \\
\text { depth }\end{array}$ & Remarks \\
\hline ALKOR & 2021 & UTC & & {$\left[{ }^{\circ} \mathbf{N}\right]$} & {$\left[{ }^{\circ} \mathbf{E}\right]$} & {$[\mathbf{m}]$} & \\
\hline AL552_1-1 & 16.03 & $12: 57$ & $\mathrm{CTD}$ & $54^{\circ} 34.658^{\prime} \mathrm{N}$ & $011^{\circ} 03.793^{\prime} \mathrm{E}$ & 22.00 & in the water \\
\hline AL552_2-1 & 16.03 & $13: 02$ & SES2000 & $54^{\circ} 34.662^{\prime} \mathrm{N}$ & $011^{\circ} 03.769^{\prime} \mathrm{E}$ & 21.00 & profile start \\
\hline AL552_2-1 & 16.03 & $13: 50$ & SES2000 & $54^{\circ} 35.681^{\prime} \mathrm{N}$ & $010^{\circ} 57.362^{\prime} \mathrm{E}$ & 23.00 & alter course \\
\hline AL552_2-2 & 16.03 & $13: 53$ & CTD & $54^{\circ} 35.702^{\prime} \mathrm{N}$ & $010^{\circ} 57.432^{\prime} \mathrm{E}$ & 23.00 & in the water \\
\hline AL552_2-3 & 16.03 & $14: 01$ & SES2000 & $54^{\circ} 35.749^{\prime} \mathrm{N}$ & $010^{\circ} 57.404^{\prime} \mathrm{E}$ & 23.00 & profile start \\
\hline AL552_3-1 & 16.03 & $14: 50$ & CTD & $54^{\circ} 34.718^{\prime} \mathrm{N}$ & $011^{\circ} 03.966^{\prime} \mathrm{E}$ & 21.00 & in the water \\
\hline AL552_4-1 & 16.03 & $14: 59$ & Multibeam & $54^{\circ} 34.687^{\prime} \mathrm{N}$ & $011^{\circ} 03.874^{\prime} \mathrm{E}$ & 21.00 & profile start \\
\hline AL552_4-1 & 16.03 & $15: 10$ & Multibeam & $54^{\circ} 34.697^{\prime} \mathrm{N}$ & $011^{\circ} 03.872^{\prime} \mathrm{E}$ & 21.00 & profile start \\
\hline AL552_5-1 & 16.03 & $15: 12$ & Multibeam & $54^{\circ} 34.676^{\prime} \mathrm{N}$ & $011^{\circ} 03.745^{\prime} \mathrm{E}$ & 21.00 & profile start \\
\hline AL552_6-1 & 16.03 & $16: 06$ & Multibeam & $54^{\circ} 35.007^{\prime} \mathrm{N}$ & $011^{\circ} 02.390^{\prime} \mathrm{E}$ & 24.00 & profile start \\
\hline AL552_7-1 & 17.03 & $10: 57$ & CTD & $54^{\circ} 34.489^{\prime} \mathrm{N}$ & $011^{\circ} 02.481^{\prime} \mathrm{E}$ & 18.00 & in the water \\
\hline AL552_8-1 & 17.03 & $11: 02$ & USBL-EvoLogics & $54^{\circ} 34.514^{\prime} \mathrm{N}$ & $011^{\circ} 02.463^{\prime} \mathrm{E}$ & 17.00 & deployed \\
\hline AL552_9-1 & 17.03 & $12: 37$ & van Veen Grab & $54^{\circ} 35.083^{\prime} \mathrm{N}$ & $010^{\circ} 59.721^{\prime} \mathrm{E}$ & 20.00 & in the water \\
\hline AL552_10-1 & 17.03 & $12: 45$ & van Veen Grab & $54^{\circ} 35.070^{\prime} \mathrm{N}$ & $010^{\circ} 59.739^{\prime} \mathrm{E}$ & 20.00 & in the water \\
\hline AL552_11-1 & 17.03 & 13:01 & van Veen Grab & $54^{\circ} 35.103^{\prime} \mathrm{N}$ & $010^{\circ} 59.700^{\prime} \mathrm{E}$ & 20.00 & in the water \\
\hline AL552_12-1 & 17.03 & $13: 12$ & van Veen Grab & $54^{\circ} 35.124^{\prime} \mathrm{N}$ & $010^{\circ} 59.660^{\prime} \mathrm{E}$ & 20.00 & in the water \\
\hline AL552_13-1 & 17.03 & $13: 21$ & van Veen Grab & $54^{\circ} 35.155^{\prime} \mathrm{N}$ & $010^{\circ} 59.609^{\prime} \mathrm{E}$ & 21.00 & in the water \\
\hline AL552_14-1 & 17.03 & $13: 36$ & van Veen Grab & $54^{\circ} 35.202^{\prime} \mathrm{N}$ & $010^{\circ} 59.719^{\prime} \mathrm{E}$ & 22.00 & in the water \\
\hline AL552_14-2 & 17.03 & $13: 40$ & CTD & $54^{\circ} 35.193^{\prime} \mathrm{N}$ & $010^{\circ} 59.724^{\prime} \mathrm{E}$ & 22.00 & in the water \\
\hline AL552_15-1 & 17.03 & $13: 47$ & van Veen Grab & $54^{\circ} 35.200^{\prime} \mathrm{N}$ & $010^{\circ} 59.685^{\prime} \mathrm{E}$ & 20.00 & in the water \\
\hline AL552_16-1 & 17.03 & $13: 55$ & van Veen Grab & $54^{\circ} 35.195^{\prime} \mathrm{N}$ & $010^{\circ} 59.638^{\prime} \mathrm{E}$ & 22.00 & in the water \\
\hline AL552_17-1 & 17.03 & $14: 03$ & van Veen Grab & $54^{\circ} 35.193^{\prime} \mathrm{N}$ & $010^{\circ} 59.595^{\prime} \mathrm{E}$ & 20.00 & in the water \\
\hline AL552_18-1 & 17.03 & $14: 13$ & van Veen Grab & $54^{\circ} 35.249^{\prime} \mathrm{N}$ & $010^{\circ} 59.699^{\prime} \mathrm{E}$ & 23.00 & in the water \\
\hline AL552_18-2 & 17.03 & $14: 17$ & CTD & $54^{\circ} 35.242^{\prime} \mathrm{N}$ & $010^{\circ} 59.697^{\prime} \mathrm{E}$ & 23.00 & in the water \\
\hline AL552_19-1 & 17.03 & $14: 23$ & van Veen Grab & $54^{\circ} 35.240^{\prime} \mathrm{N}$ & $010^{\circ} 59.661^{\prime} \mathrm{E}$ & 21.00 & in the water \\
\hline AL552_20-1 & 17.03 & $14: 35$ & van Veen Grab & $54^{\circ} 35.242^{\prime} \mathrm{N}$ & $010^{\circ} 59.620^{\prime} \mathrm{E}$ & 22.00 & in the water \\
\hline AL552_21-1 & 17.03 & $14: 45$ & van Veen Grab & $54^{\circ} 35.241^{\prime} \mathrm{N}$ & $010^{\circ} 59.572^{\prime} \mathrm{E}$ & 21.00 & in the water \\
\hline AL552_22-1 & 17.03 & $14: 58$ & van Veen Grab & $54^{\circ} 35.289^{\prime} \mathrm{N}$ & $010^{\circ} 59.718^{\prime} \mathrm{E}$ & 23.00 & in the water \\
\hline AL552_23-1 & 17.03 & $15: 07$ & van Veen Grab & $54^{\circ} 35.288^{\prime} \mathrm{N}$ & $010^{\circ} 59.660^{\prime} \mathrm{E}$ & 23.00 & in the water \\
\hline AL552_24-1 & 17.03 & $15: 18$ & van Veen Grab & $54^{\circ} 35.323^{\prime} \mathrm{N}$ & $010^{\circ} 59.603^{\prime} \mathrm{E}$ & 23.00 & in the water \\
\hline AL552_25-1 & 17.03 & $15: 25$ & van Veen Grab & $54^{\circ} 35.285^{\prime} \mathrm{N}$ & $010^{\circ} 59.613^{\prime} \mathrm{E}$ & 22.00 & in the water \\
\hline AL552_26-1 & 17.03 & $15: 35$ & van Veen Grab & $54^{\circ} 35.287^{\prime} \mathrm{N}$ & $010^{\circ} 59.567^{\prime} \mathrm{E}$ & 23.00 & in the water \\
\hline AL552_27-1 & 17.03 & $18: 16$ & CTD & $54^{\circ} 31.515^{\prime} \mathrm{N}$ & $011^{\circ} 16.023^{\prime} \mathrm{E}$ & 26.00 & in the water \\
\hline AL552_28-1 & 17.03 & $18: 27$ & Multibeam & $54^{\circ} 31.759^{\prime} \mathrm{N}$ & $011^{\circ} 15.253^{\prime} \mathrm{E}$ & 25.00 & profile start \\
\hline AL552_29-1 & 17.03 & 19:06 & CTD & $54^{\circ} 34.675^{\prime} \mathrm{N}$ & $011^{\circ} 17.607^{\prime} \mathrm{E}$ & 29.00 & in the water \\
\hline AL552_30-1 & 17.03 & $20: 35$ & CTD & $54^{\circ} 34.652^{\prime} \mathrm{N}$ & $011^{\circ} 17.694^{\prime} \mathrm{E}$ & 29.00 & in the water \\
\hline AL552_31-1 & 17.03 & $22: 07$ & CTD & $54^{\circ} 34.651^{\prime} \mathrm{N}$ & $011^{\circ} 17.844^{\prime} \mathrm{E}$ & 29.00 & in the water \\
\hline AL552_32-1 & 17.03 & $23: 42$ & CTD & $54^{\circ} 34.682^{\prime} \mathrm{N}$ & $011^{\circ} 17.944^{\prime} \mathrm{E}$ & 29.00 & in the water \\
\hline AL552_33-1 & 18.03 & $1: 21$ & CTD & $54^{\circ} 34.611^{\prime} \mathrm{N}$ & $011^{\circ} 18.036^{\prime} \mathrm{E}$ & 28.00 & in the water \\
\hline AL552_34-1 & 18.03 & $2: 58$ & CTD & $54^{\circ} 34.557^{\prime} \mathrm{N}$ & $011^{\circ} 18.120^{\prime} \mathrm{E}$ & 28.00 & in the water \\
\hline AL552_35-1 & 18.03 & $4: 38$ & CTD & $54^{\circ} 34.499^{\prime} \mathrm{N}$ & $011^{\circ} 18.280^{\prime} \mathrm{E}$ & 28.00 & in the water \\
\hline AL552_36-1 & 18.03 & 6:09 & CTD & $54^{\circ} 34.497^{\prime} \mathrm{N}$ & $011^{\circ} 18.350^{\prime} \mathrm{E}$ & 28.00 & in the water \\
\hline AL552_36-2 & 18.03 & $6: 15$ & CTD & $54^{\circ} 34.527^{\prime} \mathrm{N}$ & $011^{\circ} 18.340^{\prime} \mathrm{E}$ & 28.00 & in the water \\
\hline AL552_37-1 & 18.03 & $7: 02$ & $\mathrm{CTD}$ & $54^{\circ} 31.454^{\prime} \mathrm{N}$ & $011^{\circ} 15.930^{\prime} \mathrm{E}$ & 25.00 & in the water \\
\hline AL552_38-1 & 18.03 & $7: 47$ & CTD & $54^{\circ} 34.422^{\prime} \mathrm{N}$ & $011^{\circ} 18.459^{\prime} \mathrm{E}$ & 28.00 & in the water \\
\hline AL552_39-1 & 18.03 & $8: 34$ & CTD & $54^{\circ} 31.365^{\prime} \mathrm{N}$ & $011^{\circ} 15.955^{\prime} \mathrm{E}$ & 24.00 & in the water \\
\hline AL552_40-1 & 18.03 & $9: 25$ & $\mathrm{CTD}$ & $54^{\circ} 34.414^{\prime} \mathrm{N}$ & $011^{\circ} 18.553^{\prime} \mathrm{E}$ & 28.00 & in the water \\
\hline AL552_41-1 & 18.03 & $10: 58$ & CTD & $54^{\circ} 34.434^{\prime} \mathrm{N}$ & $011^{\circ} 18.689^{\prime} \mathrm{E}$ & 28.00 & in the water \\
\hline AL552_42-1 & 18.03 & $11: 20$ & CTD & $54^{\circ} 34.284^{\prime} \mathrm{N}$ & $011^{\circ} 18.548^{\prime} \mathrm{E}$ & 28.00 & in the water \\
\hline AL552_43-1 & 18.03 & $11: 34$ & CTD & $54^{\circ} 34.034^{\prime} \mathrm{N}$ & $011^{\circ} 18.419^{\prime} \mathrm{E}$ & 29.00 & in the water \\
\hline
\end{tabular}




\begin{tabular}{|c|c|c|c|c|c|c|c|}
\hline AL552_44-1 & 18.03 & $11: 45$ & CTD & $54^{\circ} 33.828^{\prime} \mathrm{N}$ & 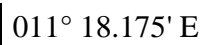 & 29.00 & in the water \\
\hline AL552_45-1 & 18.03 & $11: 57$ & CTD & $54^{\circ} 33.625^{\prime} \mathrm{N}$ & $011^{\circ} 17.987^{\prime} \mathrm{E}$ & 29.00 & in the water \\
\hline AL552_46-1 & 18.03 & 12:09 & CTD & $54^{\circ} 33.394^{\prime} \mathrm{N}$ & $011^{\circ} 17.828^{\prime} \mathrm{E}$ & 29.00 & in the water \\
\hline AL552_47-1 & 18.03 & $12: 21$ & CTD & $54^{\circ} 33.135^{\prime} \mathrm{N}$ & $011^{\circ} 17.567^{\prime} \mathrm{E}$ & 29.00 & in the water \\
\hline AL552_48-1 & 18.03 & $12: 35$ & CTD & $54^{\circ} 32.823^{\prime} \mathrm{N}$ & $011^{\circ} 17.361^{\prime} \mathrm{E}$ & 29.00 & in the water \\
\hline AL552_49-1 & 18.03 & $12: 46$ & CTD & $54^{\circ} 32.529^{\prime} \mathrm{N}$ & $011^{\circ} 17.120^{\prime} \mathrm{E}$ & 29.00 & in the water \\
\hline AL552_50-1 & 18.03 & $12: 57$ & CTD & $54^{\circ} 32.256^{\prime} \mathrm{N}$ & $011^{\circ} 16.894^{\prime} \mathrm{E}$ & 29.00 & in the water \\
\hline AL552_51-1 & 18.03 & 13:07 & CTD & $54^{\circ} 32.006^{\prime} \mathrm{N}$ & $011^{\circ} 16.705^{\prime} \mathrm{E}$ & 28.00 & in the water \\
\hline AL552_52-1 & 18.03 & $13: 19$ & CTD & $54^{\circ} 31.743^{\prime} \mathrm{N}$ & $011^{\circ} 16.506^{\prime} \mathrm{E}$ & 28.00 & in the water \\
\hline AL552_53-1 & 18.03 & $13: 29$ & CTD & $54^{\circ} 31.489^{\prime} \mathrm{N}$ & $011^{\circ} 16.285^{\prime} \mathrm{E}$ & 26.00 & in the water \\
\hline AL552_54-1 & 18.03 & $14: 22$ & CTD & $54^{\circ} 34.455^{\prime} \mathrm{N}$ & $011^{\circ} 18.732^{\prime} \mathrm{E}$ & 28.00 & in the water \\
\hline AL552_55-1 & 18.03 & $15: 53$ & CTD & $54^{\circ} 34.378^{\prime} \mathrm{N}$ & $011^{\circ} 18.772^{\prime} \mathrm{E}$ & 28.00 & in the water \\
\hline AL552_56-1 & 18.03 & $17: 30$ & CTD & $54^{\circ} 34.287^{\prime} \mathrm{N}$ & $011^{\circ} 18.874^{\prime} \mathrm{E}$ & 28.00 & in the water \\
\hline AL552_57-1 & 18.03 & $18: 14$ & CTD & $54^{\circ} 31.279^{\prime} \mathrm{N}$ & $011^{\circ} 16.478^{\prime} \mathrm{E}$ & 25.00 & in the water \\
\hline AL552_58-1 & 18.03 & $19: 00$ & CTD & $54^{\circ} 30.191^{\prime} \mathrm{N}$ & $011^{\circ} 21.007^{\prime} \mathrm{E}$ & 29.00 & in the water \\
\hline AL552_59-1 & 18.03 & 19:11 & Multibeam & $54^{\circ} 30.126^{\prime} \mathrm{N}$ & $011^{\circ} 21.632^{\prime} \mathrm{E}$ & 29.00 & profile start \\
\hline AL552_60-1 & 18.03 & $20: 03$ & CTD & $54^{\circ} 30.208^{\prime} \mathrm{N}$ & $011^{\circ} 21.635^{\prime} \mathrm{E}$ & 29.00 & in the water \\
\hline AL552_61-1 & 18.03 & 21:01 & CTD & $54^{\circ} 30.291^{\prime} \mathrm{N}$ & $011^{\circ} 21.700^{\prime} \mathrm{E}$ & 29.00 & in the water \\
\hline AL552_62-1 & 18.03 & $22: 00$ & CTD & $54^{\circ} 30.351^{\prime} \mathrm{N}$ & $011^{\circ} 21.773^{\prime} \mathrm{E}$ & 29.00 & in the water \\
\hline AL552_63-1 & 18.03 & 23:01 & CTD & $54^{\circ} 30.430^{\prime} \mathrm{N}$ & $011^{\circ} 21.707^{\prime} \mathrm{E}$ & 30.00 & in the water \\
\hline AL552_64-1 & 19.03 & 0:03 & CTD & $54^{\circ} 30.468^{\prime} \mathrm{N}$ & $011^{\circ} 21.848^{\prime} \mathrm{E}$ & 30.00 & in the water \\
\hline AL552_65-1 & 19.03 & 1:09 & CTD & $54^{\circ} 30.531^{\prime} \mathrm{N}$ & $011^{\circ} 21.883^{\prime} \mathrm{E}$ & 30.00 & in the water \\
\hline AL552_66-1 & 19.03 & $2: 12$ & CTD & $54^{\circ} 30.591^{\prime} \mathrm{N}$ & $011^{\circ} 21.972^{\prime} \mathrm{E}$ & 30.00 & in the water \\
\hline AL552_67-1 & 19.03 & $3: 16$ & CTD & $54^{\circ} 30.638^{\prime} \mathrm{N}$ & $011^{\circ} 22.069^{\prime} \mathrm{E}$ & 30.00 & in the water \\
\hline AL552_68-1 & 19.03 & $4: 15$ & CTD & $54^{\circ} 30.702^{\prime} \mathrm{N}$ & $011^{\circ} 22.110^{\prime} \mathrm{E}$ & 30.00 & in the water \\
\hline AL552_69-1 & 19.03 & $5: 18$ & CTD & $54^{\circ} 30.779^{\prime} \mathrm{N}$ & $011^{\circ} 22.131^{\prime} \mathrm{E}$ & 30.00 & in the water \\
\hline AL552_70-1 & 19.03 & $6: 19$ & CTD & $54^{\circ} 30.863^{\prime} \mathrm{N}$ & $011^{\circ} 22.164^{\prime} \mathrm{E}$ & 30.00 & in the water \\
\hline AL552_71-1 & 19.03 & $7: 18$ & CTD & $54^{\circ} 30.907^{\prime} \mathrm{N}$ & $011^{\circ} 22.339^{\prime} \mathrm{E}$ & 30.00 & in the water \\
\hline AL552_72-1 & 19.03 & $7: 30$ & SES2000 & $54^{\circ} 30.575^{\prime} \mathrm{N}$ & $011^{\circ} 22.038^{\prime} \mathrm{E}$ & 30.00 & profile start \\
\hline AL552_73-1 & 19.03 & $8: 19$ & SES2000 & $54^{\circ} 29.584^{\prime} \mathrm{N}$ & $011^{\circ} 24.649^{\prime} \mathrm{E}$ & 29.00 & profile start \\
\hline AL552_74-1 & 19.03 & $8: 44$ & SES2000 & $54^{\circ} 30.226^{\prime} \mathrm{N}$ & $011^{\circ} 22.743^{\prime} \mathrm{E}$ & 30.00 & profile start \\
\hline AL552_75-1 & 19.03 & 9:03 & van Veen Grab & $54^{\circ} 30.283^{\prime} \mathrm{N}$ & $011^{\circ} 22.741^{\prime} \mathrm{E}$ & 30.00 & in the water \\
\hline AL552_76-1 & 19.03 & $9: 15$ & van Veen Grab & $54^{\circ} 30.274^{\prime} \mathrm{N}$ & $011^{\circ} 22.747^{\prime} \mathrm{E}$ & 30.00 & in the water \\
\hline AL552_77-1 & 19.03 & $9: 30$ & van Veen Grab & $54^{\circ} 30.273^{\prime} \mathrm{N}$ & $011^{\circ} 22.781^{\prime} \mathrm{E}$ & 30.00 & in the water \\
\hline AL552_78-1 & 19.03 & $9: 36$ & van Veen Grab & $54^{\circ} 30.264^{\prime} \mathrm{N}$ & $011^{\circ} 22.772^{\prime} \mathrm{E}$ & 30.00 & in the water \\
\hline AL552_79-1 & 19.03 & 9:46 & van Veen Grab & $54^{\circ} 30.255^{\prime} \mathrm{N}$ & $011^{\circ} 22.779^{\prime} \mathrm{E}$ & 30.00 & in the water \\
\hline AL552_80-1 & 19.03 & $9: 55$ & van Veen Grab & $54^{\circ} 30.264^{\prime} \mathrm{N}$ & $011^{\circ} 22.786^{\prime} \mathrm{E}$ & 30.00 & in the water \\
\hline AL552_80-2 & 19.03 & 10:05 & van Veen Grab & $54^{\circ} 30.267^{\prime} \mathrm{N}$ & $011^{\circ} 22.779^{\prime} \mathrm{E}$ & 30.00 & in the water \\
\hline AL552_81-1 & 19.03 & $10: 48$ & van Veen Grab & $54^{\circ} 30.277^{\prime} \mathrm{N}$ & $011^{\circ} 22.791^{\prime} \mathrm{E}$ & 30.00 & in the water \\
\hline AL552_82-1 & 19.03 & $10: 57$ & van Veen Grab & $54^{\circ} 30.281^{\prime} \mathrm{N}$ & $011^{\circ} 22.811^{\prime} \mathrm{E}$ & 30.00 & in the water \\
\hline AL552_83-1 & 19.03 & 11:09 & van Veen Grab & $54^{\circ} 30.262^{\prime} \mathrm{N}$ & $011^{\circ} 22.808^{\prime} \mathrm{E}$ & 30.00 & in the water \\
\hline AL552_84-1 & 19.03 & $11: 37$ & van Veen Grab & $54^{\circ} 29.602^{\prime} \mathrm{N}$ & $011^{\circ} 24.701^{\prime} \mathrm{E}$ & 30.00 & in the water \\
\hline AL552_85-1 & 19.03 & $11: 52$ & van Veen Grab & $54^{\circ} 29.621^{\prime} \mathrm{N}$ & $011^{\circ} 24.704^{\prime} \mathrm{E}$ & 29.00 & in the water \\
\hline AL552_87-1 & 19.03 & 12:09 & van Veen Grab & $54^{\circ} 29.617^{\prime} \mathrm{N}$ & $011^{\circ} 24.750^{\prime} \mathrm{E}$ & 29.00 & in the water \\
\hline AL552_86-1 & 19.03 & $12: 01$ & van Veen Grab & $54^{\circ} 29.621^{\prime} \mathrm{N}$ & $011^{\circ} 24.735^{\prime} \mathrm{E}$ & 30.00 & in the water \\
\hline AL552_88-1 & 19.03 & $12: 21$ & van Veen Grab & $54^{\circ} 29.630^{\prime} \mathrm{N}$ & $011^{\circ} 24.715^{\prime} \mathrm{E}$ & 29.00 & in the water \\
\hline AL552_89-1 & 19.03 & $12: 33$ & van Veen Grab & $54^{\circ} 29.641^{\prime} \mathrm{N}$ & $011^{\circ} 24.676^{\prime} \mathrm{E}$ & 30.00 & in the water \\
\hline AL552_90-1 & 19.03 & $12: 43$ & van Veen Grab & $54^{\circ} 29.636^{\prime} \mathrm{N}$ & $011^{\circ} 24.698^{\prime} \mathrm{E}$ & 29.00 & in the water \\
\hline AL552_91-1 & 19.03 & $12: 52$ & van Veen Grab & $54^{\circ} 29.640^{\prime} \mathrm{N}$ & $011^{\circ} 24.725^{\prime} \mathrm{E}$ & 29.00 & in the water \\
\hline AL552_92-1 & 19.03 & 13:04 & van Veen Grab & $54^{\circ} 29.644^{\prime} \mathrm{N}$ & $011^{\circ} 24.749^{\prime} \mathrm{E}$ & 29.00 & in the water \\
\hline AL552_93-1 & 19.03 & 13:27 & Multibeam & $54^{\circ} 29.534^{\prime} \mathrm{N}$ & $011^{\circ} 23.775^{\prime} \mathrm{E}$ & 29.00 & profile start \\
\hline AL552_94-1 & 19.03 & $20: 37$ & CTD & $54^{\circ} 03.393^{\prime} \mathrm{N}$ & $010^{\circ} 58.164^{\prime} \mathrm{E}$ & 24.00 & in the water \\
\hline AL552_95-1 & 19.03 & $20: 40$ & Multibeam & $54^{\circ} 03.392^{\prime} \mathrm{N}$ & $010^{\circ} 58.176^{\prime} \mathrm{E}$ & 24.00 & profile start \\
\hline AL552_96-1 & 20.03 & $1: 08$ & Multibeam & $54^{\circ} 03.448^{\prime} \mathrm{N}$ & $010^{\circ} 57.455^{\prime} \mathrm{E}$ & 24.00 & profile start \\
\hline AL552_97-1 & 20.03 & $2: 08$ & Multibeam & $54^{\circ} 04.952^{\prime} \mathrm{N}$ & $010^{\circ} 55.792^{\prime} \mathrm{E}$ & 21.00 & profile start \\
\hline
\end{tabular}




\begin{tabular}{|c|c|c|c|c|c|c|c|}
\hline AL552_98-1 & 20.03 & $9: 46$ & UW Video & $54^{\circ} 04.557^{\prime} \mathrm{N}$ & $010^{\circ} 56.053^{\prime} \mathrm{E}$ & 22.00 & in the water \\
\hline AL552_98-1 & 20.03 & $10: 11$ & UW Video & $54^{\circ} 04.545^{\prime} \mathrm{N}$ & $010^{\circ} 55.966^{\prime} \mathrm{E}$ & 22.00 & in the water \\
\hline AL552_99-1 & 20.03 & $12: 33$ & UW Video & $54^{\circ} 02.917^{\prime} \mathrm{N}$ & $010^{\circ} 57.666^{\prime} \mathrm{E}$ & 24.00 & profile start \\
\hline AL552_99-1 & 20.03 & $13: 13$ & UW Video & $54^{\circ} 02.911^{\prime} \mathrm{N}$ & $010^{\circ} 57.634^{\prime} \mathrm{E}$ & 24.00 & profile start \\
\hline AL552_100-1 & 20.03 & $14: 09$ & UW Video & $54^{\circ} 02.834^{\prime} \mathrm{N}$ & $010^{\circ} 57.606^{\prime} \mathrm{E}$ & 24.00 & in the water \\
\hline AL552_101-1 & 20.03 & $15: 38$ & CTD & $54^{\circ} 03.599^{\prime} \mathrm{N}$ & $010^{\circ} 55.972^{\prime} \mathrm{E}$ & 23.00 & in the water \\
\hline AL552_102-1 & 20.03 & $15: 53$ & Sidescan Sonar & $54^{\circ} 03.592^{\prime} \mathrm{N}$ & $010^{\circ} 56.054^{\prime} \mathrm{E}$ & 23.00 & in the water \\
\hline AL552_102-1 & 20.03 & $16: 35$ & Sidescan Sonar & $54^{\circ} 05.240^{\prime} \mathrm{N}$ & $010^{\circ} 57.563^{\prime} \mathrm{E}$ & 21.00 & profile start \\
\hline AL552_103-1 & 21.03 & 8:04 & CTD & $54^{\circ} 04.835^{\prime} \mathrm{N}$ & $010^{\circ} 55.519^{\prime} \mathrm{E}$ & 21.00 & in the water \\
\hline AL552_104-1 & 21.03 & $8: 11$ & van Veen Grab & $54^{\circ} 04.846^{\prime} \mathrm{N}$ & $010^{\circ} 55.485^{\prime} \mathrm{E}$ & 21.00 & in the water \\
\hline AL552_105-1 & 21.03 & $8: 20$ & van Veen Grab & $54^{\circ} 04.653^{\prime} \mathrm{N}$ & $010^{\circ} 55.351^{\prime} \mathrm{E}$ & 21.00 & in the water \\
\hline AL552_106-1 & 21.03 & $8: 30$ & van Veen Grab & $54^{\circ} 04.536^{\prime} \mathrm{N}$ & $010^{\circ} 55.359^{\prime} \mathrm{E}$ & 22.00 & in the water \\
\hline AL552_107-1 & 21.03 & $8: 41$ & van Veen Grab & $54^{\circ} 04.525^{\prime} \mathrm{N}$ & $010^{\circ} 55.337^{\prime} \mathrm{E}$ & 22.00 & in the water \\
\hline AL552_108-1 & 21.03 & $8: 53$ & van Veen Grab & $54^{\circ} 04.505^{\prime} \mathrm{N}$ & $010^{\circ} 55.416^{\prime} \mathrm{E}$ & 22.00 & in the water \\
\hline AL552_108-2 & 21.03 & 9:01 & van Veen Grab & $54^{\circ} 04.514^{\prime} \mathrm{N}$ & $010^{\circ} 55.424^{\prime} \mathrm{E}$ & 22.00 & in the water \\
\hline AL552_109-1 & 21.03 & 9:08 & van Veen Grab & $54^{\circ} 04.504^{\prime} \mathrm{N}$ & $010^{\circ} 55.533^{\prime} \mathrm{E}$ & 21.00 & in the water \\
\hline AL552_110-1 & 21.03 & $9: 22$ & van Veen Grab & $54^{\circ} 04.481^{\prime} \mathrm{N}$ & $010^{\circ} 55.801^{\prime} \mathrm{E}$ & 22.00 & in the water \\
\hline AL552_111-1 & 21.03 & $9: 38$ & van Veen Grab & $54^{\circ} 04.245^{\prime} \mathrm{N}$ & $010^{\circ} 55.162^{\prime} \mathrm{E}$ & 22.00 & in the water \\
\hline AL552_112-1 & 21.03 & $9: 51$ & van Veen Grab & $54^{\circ} 04.206^{\prime} \mathrm{N}$ & $010^{\circ} 55.140^{\prime} \mathrm{E}$ & 22.00 & in the water \\
\hline AL552_113-1 & 21.03 & 10:03 & van Veen Grab & $54^{\circ} 04.187^{\prime} \mathrm{N}$ & $010^{\circ} 55.123^{\prime} \mathrm{E}$ & 22.00 & in the water \\
\hline AL552_114-1 & 21.03 & $11: 15$ & van Veen Grab & $54^{\circ} 02.893^{\prime} \mathrm{N}$ & $010^{\circ} 57.493^{\prime} \mathrm{E}$ & 25.00 & in the water \\
\hline AL552_115-1 & 21.03 & $11: 21$ & van Veen Grab & $54^{\circ} 02$ & $010^{\circ} 57$ & 25.00 & in the water \\
\hline AL552_116-1 & 21.03 & $11: 41$ & van Veen Grab & $54^{\circ} 02.838^{\prime} \mathrm{N}$ & $010^{\circ} 57.446^{\prime} \mathrm{E}$ & 25.00 & in the water \\
\hline AL552_117-1 & 21.03 & $11: 49$ & van Veen Grab & $54^{\circ} 02.844^{\prime} \mathrm{N}$ & $010^{\circ} 57.426^{\prime} \mathrm{E}$ & 25.00 & in the water \\
\hline AL552_118-1 & 21.03 & $12: 02$ & van Veen Grab & $54^{\circ} 02.750^{\prime} \mathrm{N}$ & $010^{\circ} 57.337^{\prime} \mathrm{E}$ & 24.00 & in the water \\
\hline AL552_119-1 & 21.03 & $12: 14$ & van Veen Grab & $54^{\circ} 02.776^{\prime} \mathrm{N}$ & $010^{\circ} 57.169^{\prime} \mathrm{E}$ & 24.00 & in the water \\
\hline AL552_120-1 & 21.03 & $12: 23$ & van Veen Grab & $54^{\circ} 02.806^{\prime} \mathrm{N}$ & $010^{\circ} 57.137^{\prime} \mathrm{E}$ & 24.00 & in the water \\
\hline AL552_121-1 & 21.03 & $12: 31$ & van Veen Grab & $54^{\circ} 02.818^{\prime} \mathrm{N}$ & $010^{\circ} 57.147^{\prime} \mathrm{E}$ & 24.00 & in the water \\
\hline AL552_122-1 & 21.03 & $12: 45$ & van Veen Grab & $54^{\circ} 02.990^{\prime} \mathrm{N}$ & $010^{\circ} 57.175^{\prime} \mathrm{E}$ & 25.00 & in the water \\
\hline AL552_123-1 & 21.03 & $13: 30$ & UW Video & $54^{\circ} 05.014^{\prime} \mathrm{N}$ & $010^{\circ} 58.026^{\prime} \mathrm{E}$ & 22.00 & in the water \\
\hline AL552_124-1 & 21.03 & $14: 28$ & UW Video & $54^{\circ} 05.279^{\prime} \mathrm{N}$ & $010^{\circ} 59.358^{\prime} \mathrm{E}$ & 23.00 & in the water \\
\hline AL552__125-1 & 21.03 & $16: 14$ & Multibeam & $54^{\circ} 05.934^{\prime} \mathrm{N}$ & $010^{\circ} 59.164^{\prime} \mathrm{E}$ & 22.00 & profile start \\
\hline AL552_126-1 & 21.03 & $19: 47$ & Multibeam & $54^{\circ} 08.234^{\prime} \mathrm{N}$ & $010^{\circ} 59.367^{\prime} \mathrm{E}$ & 14.00 & profile start \\
\hline AL552_127-1 & 22.03 & 4:08 & SES2000 & $54^{\circ} 08.643^{\prime} \mathrm{N}$ & $011^{\circ} 00.081^{\prime} \mathrm{E}$ & 16.00 & profile start \\
\hline AL552_128-1 & 22.03 & $5: 48$ & SES2000 & $54^{\circ} 08.921^{\prime} \mathrm{N}$ & $011^{\circ} 02.814^{\prime} \mathrm{E}$ & 20.00 & profile start \\
\hline AL552_129-1 & 22.03 & $8: 31$ & SES2000 & $54^{\circ} 08.209^{\prime} \mathrm{N}$ & $011^{\circ} 03.480^{\prime} \mathrm{E}$ & 21.00 & profile start \\
\hline AL552_130-1 & 22.03 & 9:05 & Gravity Corer & $54^{\circ} 08.862^{\prime} \mathrm{N}$ & $011^{\circ} 02.541^{\prime} \mathrm{E}$ & 20.00 & in the water \\
\hline AL552_130-2 & 22.03 & $9: 36$ & Gravity Corer & $54^{\circ} 08.871^{\prime} \mathrm{N}$ & $011^{\circ} 02.541^{\prime} \mathrm{E}$ & 20.00 & in the water \\
\hline AL552_131-1 & 22.03 & $11: 29$ & Gravity Corer & $54^{\circ} 08.696^{\prime} \mathrm{N}$ & $011^{\circ} 02.755^{\prime} \mathrm{E}$ & 20.00 & in the water \\
\hline AL552_132-1 & 22.03 & $12: 02$ & Gravity Corer & $54^{\circ} 08.421^{\prime} \mathrm{N}$ & $011^{\circ} 03.119^{\prime} \mathrm{E}$ & 21.00 & in the water \\
\hline AL552_133-1 & 22.03 & $13: 37$ & ADCP & $54^{\circ} 12.763^{\prime} \mathrm{N}$ & $011^{\circ} 10.191^{\prime} \mathrm{E}$ & 15.00 & profile start \\
\hline AL552_134-1 & 22.03 & $16: 36$ & CTD & $54^{\circ} 04.800^{\prime} \mathrm{N}$ & $011^{\circ} 26.714^{\prime} \mathrm{E}$ & 14.00 & in the water \\
\hline AL552_135-1 & 22.03 & $16: 58$ & CTD & $54^{\circ} 05.599^{\prime} \mathrm{N}$ & $011^{\circ} 25.012^{\prime} \mathrm{E}$ & 17.00 & in the water \\
\hline AL552_136-1 & 22.03 & $17: 19$ & CTD & $54^{\circ} 06.509^{\prime} \mathrm{N}$ & $011^{\circ} 23.130^{\prime} \mathrm{E}$ & 17.00 & in the water \\
\hline AL552_137-1 & 22.03 & $17: 40$ & CTD & $54^{\circ} 07.417^{\prime} \mathrm{N}$ & $011^{\circ} 21.314^{\prime} \mathrm{E}$ & 20.00 & in the water \\
\hline AL552_138-1 & 22.03 & 18:01 & CTD & $54^{\circ} 08.259^{\prime} \mathrm{N}$ & $011^{\circ} 19.565^{\prime} \mathrm{E}$ & 23.00 & in the water \\
\hline AL552_139-1 & 22.03 & $18: 22$ & CTD & $54^{\circ} 09.134^{\prime} \mathrm{N}$ & $011^{\circ} 17.761^{\prime} \mathrm{E}$ & 25.00 & in the water \\
\hline AL552_140-1 & 22.03 & $18: 43$ & CTD & $54^{\circ} 10.012^{\prime} \mathrm{N}$ & $011^{\circ} 15.956^{\prime} \mathrm{E}$ & 21.00 & in the water \\
\hline AL552_141-1 & 22.03 & 19:04 & CTD & $54^{\circ} 10.845^{\prime} \mathrm{N}$ & $011^{\circ} 14.227^{\prime} \mathrm{E}$ & 22.00 & in the water \\
\hline AL552_142-1 & 22.03 & $19: 25$ & CTD & $54^{\circ} 11.721^{\prime} \mathrm{N}$ & $011^{\circ} 12.428^{\prime} \mathrm{E}$ & 21.00 & in the water \\
\hline AL552_143-1 & 22.03 & $19: 49$ & CTD & $54^{\circ} 12.598^{\prime} \mathrm{N}$ & $011^{\circ} 10.642^{\prime} \mathrm{E}$ & 16.00 & in the water \\
\hline AL552_144-1 & 22.03 & $20: 05$ & Multibeam & $54^{\circ} 11.913^{\prime} \mathrm{N}$ & $011^{\circ} 11.440^{\prime} \mathrm{E}$ & 19.00 & profile start \\
\hline AL552_145-1 & 22.03 & 23:08 & CTD & $54^{\circ} 24.728^{\prime} \mathrm{N}$ & $011^{\circ} 22.290^{\prime} \mathrm{E}$ & 22.00 & in the water \\
\hline AL552_146-1 & 22.03 & $23: 16$ & Multibeam & $54^{\circ} 24.915^{\prime} \mathrm{N}$ & $011^{\circ} 22.260^{\prime} \mathrm{E}$ & 22.00 & profile start \\
\hline AL552_147-1 & 23.03 & $9: 19$ & Gravity Corer & $54^{\circ} 29.623^{\prime} \mathrm{N}$ & $011^{\circ} 24.704^{\prime} \mathrm{E}$ & 28.00 & in the water \\
\hline AL552_148-1 & 23.03 & $9: 43$ & Gravity Corer & $54^{\circ} 29.627^{\prime} \mathrm{N}$ & $011^{\circ} 24.693^{\prime} \mathrm{E}$ & 29.00 & in the water \\
\hline
\end{tabular}




\begin{tabular}{|c|c|c|c|c|c|c|c|}
\hline AL552_149-1 & 23.03 & $10: 48$ & CTD & $54^{\circ} 30.272^{\prime} \mathrm{N}$ & $011^{\circ} 22.915^{\prime} \mathrm{E}$ & 30.00 & in the water \\
\hline AL552_150-1 & 23.03 & 11:07 & Gravity Corer & $54^{\circ} 30.267^{\prime} \mathrm{N}$ & $011^{\circ} 22.758^{\prime} \mathrm{E}$ & 30.00 & in the water \\
\hline AL552_151-1 & 23.03 & $11: 53$ & UW Video & $54^{\circ} 30.268^{\prime} \mathrm{N}$ & $011^{\circ} 22.814^{\prime} \mathrm{E}$ & 30.00 & in the water \\
\hline AL552_152-1 & 23.03 & $13: 25$ & UW Video & $54^{\circ} 29.635^{\prime} \mathrm{N}$ & $011^{\circ} 24.793^{\prime} \mathrm{E}$ & 29.00 & in the water \\
\hline AL552_153-1 & 23.03 & $14: 38$ & CTD & $54^{\circ} 25.492^{\prime} \mathrm{N}$ & $011^{\circ} 25.436^{\prime} \mathrm{E}$ & 24.00 & in the water \\
\hline AL552_154-1 & 23.03 & $14: 46$ & Sidescan Sonar & $54^{\circ} 25.519^{\prime} \mathrm{N}$ & $011^{\circ} 25.431^{\prime} \mathrm{E}$ & 24.00 & in the water \\
\hline AL552_154-1 & 23.03 & $14: 51$ & Sidescan Sonar & $54^{\circ} 25.775^{\prime} \mathrm{N}$ & $011^{\circ} 25.374^{\prime} \mathrm{E}$ & 24.00 & profile start \\
\hline AL552_155-1 & 23.03 & 21:07 & Multibeam & $54^{\circ} 26.902^{\prime} \mathrm{N}$ & $011^{\circ} 25.454^{\prime} \mathrm{E}$ & 25.00 & profile start \\
\hline AL552_156-1 & 24.03 & $7: 02$ & CTD & $54^{\circ} 26.606^{\prime} \mathrm{N}$ & $011^{\circ} 26.713^{\prime} \mathrm{E}$ & 25.00 & in the water \\
\hline AL552_157-1 & 24.03 & $7: 10$ & UW Video & $54^{\circ} 26.593^{\prime} \mathrm{N}$ & $011^{\circ} 26.674^{\prime} \mathrm{E}$ & 25.00 & in the water \\
\hline AL552_157-1 & 24.03 & $7: 22$ & UW Video & $54^{\circ} 26.564^{\prime} \mathrm{N}$ & $011^{\circ} 26.532^{\prime} \mathrm{E}$ & 25.00 & profile start \\
\hline AL552_158-1 & 24.03 & 8:07 & CTD & $54^{\circ} 26.484^{\prime} \mathrm{N}$ & $011^{\circ} 26.095^{\prime} \mathrm{E}$ & 24.00 & in the water \\
\hline AL552_159-1 & 24.03 & $8: 41$ & CTD & $54^{\circ} 25.875^{\prime} \mathrm{N}$ & $011^{\circ} 22.923^{\prime} \mathrm{E}$ & 22.00 & in the water \\
\hline AL552_160-1 & 24.03 & $8: 50$ & UW Video & $54^{\circ} 25.869^{\prime} \mathrm{N}$ & $011^{\circ} 22.903^{\prime} \mathrm{E}$ & 22.00 & in the water \\
\hline AL552_160-1 & 24.03 & 9:09 & UW Video & $54^{\circ} 25.800^{\prime} \mathrm{N}$ & $011^{\circ} 22.787^{\prime} \mathrm{E}$ & 22.00 & profile start \\
\hline AL552_161-1 & 24.03 & $10: 01$ & UW Video & $54^{\circ} 25.351^{\prime} \mathrm{N}$ & $011^{\circ} 22.258^{\prime} \mathrm{E}$ & 21.00 & in the water \\
\hline AL552_161-1 & 24.03 & $10: 03$ & UW Video & $54^{\circ} 25.351^{\prime} \mathrm{N}$ & $011^{\circ} 22.247^{\prime} \mathrm{E}$ & 21.00 & profile start \\
\hline AL552_162-1 & 24.03 & $10: 52$ & UW Video & $54^{\circ} 25.209^{\prime} \mathrm{N}$ & $011^{\circ} 22.363^{\prime} \mathrm{E}$ & 20.00 & in the water \\
\hline AL552_163-1 & 24.03 & $12: 12$ & van Veen Grab & $54^{\circ} 25.897^{\prime} \mathrm{N}$ & $011^{\circ} 22.164^{\prime} \mathrm{E}$ & 21.00 & in the water \\
\hline AL552_164-1 & 24.03 & $12: 21$ & van Veen Grab & $54^{\circ} 25.859^{\prime} \mathrm{N}$ & $011^{\circ} 22.189^{\prime} \mathrm{E}$ & 22.00 & in the water \\
\hline AL552_165-1 & 24.03 & $12: 44$ & van Veen Grab & $54^{\circ} 25.700^{\prime} \mathrm{N}$ & $011^{\circ} 22.675^{\prime} \mathrm{E}$ & 21.00 & in the water \\
\hline AL552_166-1 & 24.03 & $12: 55$ & van Veen Grab & $54^{\circ} 25.525^{\prime} \mathrm{N}$ & $011^{\circ} 22.601^{\prime} \mathrm{E}$ & 22.00 & in the water \\
\hline AL552_167-1 & 24.03 & 13:04 & van Veen Grab & $54^{\circ} 25.322^{\prime} \mathrm{N}$ & $011^{\circ} 22.527^{\prime} \mathrm{E}$ & 21.00 & in the water \\
\hline AL552_168-1 & 24.03 & $13: 17$ & van Veen Grab & $54^{\circ} 25.137^{\prime} \mathrm{N}$ & $011^{\circ} 22.271^{\prime} \mathrm{E}$ & 21.00 & in the water \\
\hline AL552_169-2 & 24.03 & $13: 30$ & van Veen Grab & $54^{\circ} 25.157^{\prime} \mathrm{N}$ & $011^{\circ} 22.206^{\prime} \mathrm{E}$ & 20.00 & in the water \\
\hline AL552_169-2 & 24.03 & $13: 35$ & van Veen Grab & $54^{\circ} 25.162^{\prime} \mathrm{N}$ & $011^{\circ} 22.219^{\prime} \mathrm{E}$ & 20.00 & in the water \\
\hline AL552_170-1 & 24.03 & $15: 13$ & CTD & $54^{\circ} 30.907^{\prime} \mathrm{N}$ & $011^{\circ} 15.381^{\prime} \mathrm{E}$ & 18.00 & in the water \\
\hline AL552_171-1 & 24.03 & $15: 25$ & Multibeam & $54^{\circ} 31.202^{\prime} \mathrm{N}$ & $011^{\circ} 15.214^{\prime} \mathrm{E}$ & 20.00 & profile start \\
\hline AL552_172-1 & 25.03 & $6: 58$ & van Veen Grab & $54^{\circ} 30.847^{\prime} \mathrm{N}$ & $011^{\circ} 16.482^{\prime} \mathrm{E}$ & 22.00 & in the water \\
\hline AL552_173-1 & 25.03 & $7: 11$ & van Veen Grab & $54^{\circ} 30.940^{\prime} \mathrm{N}$ & $011^{\circ} 15.815^{\prime} \mathrm{E}$ & 20.00 & in the water \\
\hline AL552_174-1 & 25.03 & $7: 24$ & van Veen Grab & $54^{\circ} 30.921^{\prime} \mathrm{N}$ & $011^{\circ} 15.622^{\prime} \mathrm{E}$ & 19.00 & in the water \\
\hline AL552_175-1 & 25.03 & $7: 38$ & van Veen Grab & $54^{\circ} 31.171^{\prime} \mathrm{N}$ & $011^{\circ} 15.984^{\prime} \mathrm{E}$ & 23.00 & in the water \\
\hline AL552_176-1 & 25.03 & $7: 46$ & van Veen Grab & $54^{\circ} 31.233^{\prime} \mathrm{N}$ & $011^{\circ} 15.941^{\prime} \mathrm{E}$ & 23.00 & in the water \\
\hline AL552_177-1 & 25.03 & $7: 57$ & van Veen Grab & $54^{\circ} 31.256^{\prime} \mathrm{N}$ & $011^{\circ} 15.877^{\prime} \mathrm{E}$ & 23.00 & in the water \\
\hline AL552_178-1 & 25.03 & $8: 28$ & UW Video & $54^{\circ} 30.691^{\prime} \mathrm{N}$ & $011^{\circ} 17.127^{\prime} \mathrm{E}$ & 23.00 & in the water \\
\hline AL552_178-1 & 25.03 & $8: 37$ & UW Video & $54^{\circ} 30.647^{\prime} \mathrm{N}$ & $011^{\circ} 17.083^{\prime} \mathrm{E}$ & 22.00 & profile start \\
\hline AL552_179-1 & 25.03 & $9: 29$ & UW Video & $54^{\circ} 30.956^{\prime} \mathrm{N}$ & $011^{\circ} 15.870^{\prime} \mathrm{E}$ & 21.00 & in the water \\
\hline AL552_179-1 & 25.03 & $9: 30$ & UW Video & $54^{\circ} 30.956^{\prime} \mathrm{N}$ & $011^{\circ} 15.861^{\prime} \mathrm{E}$ & 21.00 & profile start \\
\hline AL552_180-1 & 25.03 & $10: 09$ & CTD & $54^{\circ} 30.890^{\prime} \mathrm{N}$ & $011^{\circ} 15.441^{\prime} \mathrm{E}$ & 18.00 & in the water \\
\hline AL552_181-1 & 25.03 & $10: 24$ & Multibeam & $54^{\circ} 31.117^{\prime} \mathrm{N}$ & $011^{\circ} 15.504^{\prime} \mathrm{E}$ & 20.00 & profile start \\
\hline AL552_182-1 & 25.03 & $11: 46$ & CTD & $54^{\circ} 33.998^{\prime} \mathrm{N}$ & $011^{\circ} 05.747^{\prime} \mathrm{E}$ & 18.00 & in the water \\
\hline AL552_183-1 & 25.03 & $11: 56$ & CTD & $54^{\circ} 34.400^{\prime} \mathrm{N}$ & $011^{\circ} 05.883^{\prime} \mathrm{E}$ & 23.00 & in the water \\
\hline AL552_184-1 & 25.03 & $12: 11$ & CTD & $54^{\circ} 34.814^{\prime} \mathrm{N}$ & $011^{\circ} 05.959^{\prime} \mathrm{E}$ & 26.00 & in the water \\
\hline AL552_185-1 & 25.03 & $12: 31$ & CTD & $54^{\circ} 35.246^{\prime} \mathrm{N}$ & $011^{\circ} 05.989^{\prime} \mathrm{E}$ & 27.00 & in the water \\
\hline AL552_186-1 & 25.03 & $12: 44$ & CTD & $54^{\circ} 35.569^{\prime} \mathrm{N}$ & $011^{\circ} 06.054^{\prime} \mathrm{E}$ & 30.00 & in the water \\
\hline AL552_187-1 & 25.03 & $12: 56$ & CTD & $54^{\circ} 35.905^{\prime} \mathrm{N}$ & $011^{\circ} 06.141^{\prime} \mathrm{E}$ & 26.00 & in the water \\
\hline AL552_188-1 & 25.03 & 13:07 & CTD & $54^{\circ} 36.269^{\prime} \mathrm{N}$ & $011^{\circ} 06.164^{\prime} \mathrm{E}$ & 31.00 & in the water \\
\hline AL552_189-1 & 25.03 & $13: 21$ & CTD & $54^{\circ} 36.687^{\prime} \mathrm{N}$ & $011^{\circ} 06.242^{\prime} \mathrm{E}$ & 28.00 & in the water \\
\hline AL552_190-1 & 25.03 & $13: 34$ & CTD & $54^{\circ} 37.108^{\prime} \mathrm{N}$ & $011^{\circ} 06.309^{\prime} \mathrm{E}$ & 26.00 & in the water \\
\hline AL552_191-1 & 25.03 & $13: 52$ & $\mathrm{CTD}$ & $54^{\circ} 37.149^{\prime} \mathrm{N}$ & $011^{\circ} 04.379^{\prime} \mathrm{E}$ & 24.00 & in the water \\
\hline AL552_192-1 & 25.03 & $14: 02$ & CTD & $54^{\circ} 36.758^{\prime} \mathrm{N}$ & $011^{\circ} 04.272^{\prime} \mathrm{E}$ & 24.00 & in the water \\
\hline AL552_193-1 & 25.03 & $14: 12$ & CTD & $54^{\circ} 36.346^{\prime} \mathrm{N}$ & $011^{\circ} 04.155^{\prime} \mathrm{E}$ & 30.00 & in the water \\
\hline AL552_194-1 & 25.03 & $14: 23$ & CTD & $54^{\circ} 35.992^{\prime} \mathrm{N}$ & $011^{\circ} 04.058^{\prime} \mathrm{E}$ & 29.00 & in the water \\
\hline AL552_195-1 & 25.03 & $14: 32$ & CTD & $54^{\circ} 35.618^{\prime} \mathrm{N}$ & $011^{\circ} 03.947^{\prime} \mathrm{E}$ & 34.00 & in the water \\
\hline AL552_196-1 & 25.03 & $14: 40$ & CTD & $54^{\circ} 35.355^{\prime} \mathrm{N}$ & $011^{\circ} 03.872^{\prime} \mathrm{E}$ & 30.00 & in the water \\
\hline
\end{tabular}




\begin{tabular}{|c|c|c|c|c|c|c|c|}
\hline AL552_197-1 & 25.03 & $14: 51$ & CTD & $54^{\circ} 34.953^{\prime} \mathrm{N}$ & $011^{\circ} 03.723^{\prime} \mathrm{E}$ & 25.00 & in the water \\
\hline AL552_198-1 & 25.03 & 15:01 & CTD & $54^{\circ} 34.565^{\prime} \mathrm{N}$ & $011^{\circ} 03.550^{\prime} \mathrm{E}$ & 20.00 & in the water \\
\hline AL552_199-1 & 25.03 & $15: 13$ & CTD & $54^{\circ} 34.167^{\prime} \mathrm{N}$ & $011^{\circ} 03.468^{\prime} \mathrm{E}$ & 17.00 & in the water \\
\hline AL552_200-1 & 25.03 & $15: 32$ & CTD & $54^{\circ} 34.609^{\prime} \mathrm{N}$ & $011^{\circ} 01.530^{\prime} \mathrm{E}$ & 17.00 & in the water \\
\hline AL552_201-1 & 25.03 & $15: 45$ & CTD & $54^{\circ} 34.966^{\prime} \mathrm{N}$ & $011^{\circ} 01.690^{\prime} \mathrm{E}$ & 21.00 & in the water \\
\hline AL552_202-1 & 25.03 & $15: 56$ & CTD & $54^{\circ} 35.313^{\prime} \mathrm{N}$ & $011^{\circ} 01.866^{\prime} \mathrm{E}$ & 26.00 & in the water \\
\hline AL552_203-1 & 25.03 & $16: 09$ & CTD & $54^{\circ} 35.626^{\prime} \mathrm{N}$ & $011^{\circ} 02.072^{\prime} \mathrm{E}$ & 35.00 & in the water \\
\hline AL552_204-1 & 25.03 & $16: 27$ & CTD & $54^{\circ} 35.961^{\prime} \mathrm{N}$ & $011^{\circ} 02.199^{\prime} \mathrm{E}$ & 30.00 & in the water \\
\hline AL552_205-1 & 25.03 & $16: 35$ & CTD & $54^{\circ} 36.148^{\prime} \mathrm{N}$ & $011^{\circ} 02.263^{\prime} \mathrm{E}$ & 33.00 & in the water \\
\hline AL552_206-1 & 25.03 & $16: 43$ & CTD & $54^{\circ} 36.318^{\prime} \mathrm{N}$ & $011^{\circ} 02.344^{\prime} \mathrm{E}$ & 35.00 & in the water \\
\hline AL552_207-1 & 25.03 & $16: 53$ & CTD & $54^{\circ} 36.522^{\prime} \mathrm{N}$ & $011^{\circ} 02.480^{\prime} \mathrm{E}$ & 23.00 & in the water \\
\hline AL552_208-1 & 25.03 & $17: 05$ & CTD & $54^{\circ} 36.822^{\prime} \mathrm{N}$ & $011^{\circ} 02.611^{\prime} \mathrm{E}$ & 22.00 & in the water \\
\hline AL552_209-1 & 25.03 & $17: 16$ & CTD & $54^{\circ} 37.160^{\prime} \mathrm{N}$ & $011^{\circ} 02.766^{\prime} \mathrm{E}$ & 23.00 & in the water \\
\hline AL552_210-1 & 25.03 & $17: 33$ & CTD & $54^{\circ} 37.246^{\prime} \mathrm{N}$ & $011^{\circ} 01.619^{\prime} \mathrm{E}$ & 19.00 & in the water \\
\hline AL552_211-1 & 25.03 & $17: 45$ & CTD & $54^{\circ} 36.836^{\prime} \mathrm{N}$ & $011^{\circ} 01.349^{\prime} \mathrm{E}$ & 19.00 & in the water \\
\hline AL552_212-1 & 25.03 & $17: 55$ & CTD & $54^{\circ} 36.561^{\prime} \mathrm{N}$ & $011^{\circ} 01.198^{\prime} \mathrm{E}$ & 23.00 & in the water \\
\hline AL552_213-1 & 25.03 & 18:05 & CTD & $54^{\circ} 36.280^{\prime} \mathrm{N}$ & $011^{\circ} 00.995^{\prime} \mathrm{E}$ & 30.00 & in the water \\
\hline AL552_214-1 & 25.03 & $18: 12$ & CTD & $54^{\circ} 36.193^{\prime} \mathrm{N}$ & $011^{\circ} 00.945^{\prime} \mathrm{E}$ & 41.00 & in the water \\
\hline AL552_215-1 & 25.03 & 18:21 & CTD & $54^{\circ} 36.041^{\prime} \mathrm{N}$ & $011^{\circ} 00.881^{\prime} \mathrm{E}$ & 33.00 & in the water \\
\hline AL552_216-1 & 25.03 & 18:30 & CTD & $54^{\circ} 35.916^{\prime} \mathrm{N}$ & $011^{\circ} 00.804^{\prime} \mathrm{E}$ & 29.00 & in the water \\
\hline AL552_217-1 & 25.03 & 18:41 & CTD & $54^{\circ} 35.640^{\prime} \mathrm{N}$ & $011^{\circ} 00.641^{\prime} \mathrm{E}$ & 27.00 & in the water \\
\hline AL552_218-1 & 25.03 & $18: 51$ & CTD & $54^{\circ} 35.346^{\prime} \mathrm{N}$ & $011^{\circ} 00.486^{\prime} \mathrm{E}$ & 24.00 & in the water \\
\hline AL552_219-1 & 25.03 & 19:01 & CTD & $54^{\circ} 35.119^{\prime} \mathrm{N}$ & $011^{\circ} 00.320^{\prime} \mathrm{E}$ & 21.00 & in the water \\
\hline AL552_220-1 & 25.03 & 19:11 & CTD & $54^{\circ} 34.843^{\prime} \mathrm{N}$ & $011^{\circ} 00.141^{\prime} \mathrm{E}$ & 18.00 & in the water \\
\hline AL552_221-1 & 25.03 & $19: 26$ & CTD & $54^{\circ} 35.003^{\prime} \mathrm{N}$ & $010^{\circ} 58.709^{\prime} \mathrm{E}$ & 16.00 & in the water \\
\hline AL552_222-1 & 25.03 & $19: 39$ & CTD & $54^{\circ} 35.423^{\prime} \mathrm{N}$ & $010^{\circ} 59.008^{\prime} \mathrm{E}$ & 23.00 & in the water \\
\hline AL552_223-1 & 25.03 & $19: 47$ & CTD & $54^{\circ} 35.640^{\prime} \mathrm{N}$ & $010^{\circ} 59.180^{\prime} \mathrm{E}$ & 25.00 & in the water \\
\hline AL552_224-1 & 25.03 & $19: 57$ & CTD & $54^{\circ} 35.940^{\prime} \mathrm{N}$ & $010^{\circ} 59.395^{\prime} \mathrm{E}$ & 27.00 & in the water \\
\hline AL552_225-1 & 25.03 & 20:05 & CTD & $54^{\circ} 36.132^{\prime} \mathrm{N}$ & $010^{\circ} 59.532^{\prime} \mathrm{E}$ & 26.00 & in the water \\
\hline AL552_226-1 & 25.03 & $20: 12$ & CTD & $54^{\circ} 36.299^{\prime} \mathrm{N}$ & $010^{\circ} 59.645^{\prime} \mathrm{E}$ & 36.00 & in the water \\
\hline AL552_227-1 & 25.03 & $20: 20$ & CTD & $54^{\circ} 36.476^{\prime} \mathrm{N}$ & $010^{\circ} 59.778^{\prime} \mathrm{E}$ & 26.00 & in the water \\
\hline AL552_228-1 & 25.03 & $20: 29$ & CTD & $54^{\circ} 36.695^{\prime} \mathrm{N}$ & $010^{\circ} 59.952^{\prime} \mathrm{E}$ & 18.00 & in the water \\
\hline AL552_229-1 & 25.03 & $20: 39$ & CTD & $54^{\circ} 37.095^{\prime} \mathrm{N}$ & $011^{\circ} 00.265^{\prime} \mathrm{E}$ & 17.00 & in the water \\
\hline AL552_230-1 & 25.03 & $20: 48$ & CTD & $54^{\circ} 37.473^{\prime} \mathrm{N}$ & $011^{\circ} 00.555^{\prime} \mathrm{E}$ & 18.00 & in the water \\
\hline AL552_231-1 & 25.03 & $21: 03$ & CTD & $54^{\circ} 37.820^{\prime} \mathrm{N}$ & $010^{\circ} 59.373^{\prime} \mathrm{E}$ & 22.00 & in the water \\
\hline AL552_232-1 & 25.03 & $21: 13$ & CTD & $54^{\circ} 37.582^{\prime} \mathrm{N}$ & $010^{\circ} 59.067^{\prime} \mathrm{E}$ & 20.00 & in the water \\
\hline AL552_233-1 & 25.03 & $21: 22$ & CTD & $54^{\circ} 37.265^{\prime} \mathrm{N}$ & $010^{\circ} 58.858^{\prime} \mathrm{E}$ & 20.00 & in the water \\
\hline AL552_234-1 & 25.03 & $21: 31$ & CTD & $54^{\circ} 36.969^{\prime} \mathrm{N}$ & $010^{\circ} 58.613^{\prime} \mathrm{E}$ & 27.00 & in the water \\
\hline AL552_235-1 & 25.03 & $21: 37$ & CTD & $54^{\circ} 36.823^{\prime} \mathrm{N}$ & $010^{\circ} 58.504^{\prime} \mathrm{E}$ & 27.00 & in the water \\
\hline AL552_236-1 & 25.03 & $21: 44$ & CTD & $54^{\circ} 36.673^{\prime} \mathrm{N}$ & $010^{\circ} 58.386^{\prime} \mathrm{E}$ & 34.00 & in the water \\
\hline AL552_237-1 & 25.03 & $21: 50$ & CTD & $54^{\circ} 36.545^{\prime} \mathrm{N}$ & $010^{\circ} 58.258^{\prime} \mathrm{E}$ & 30.00 & in the water \\
\hline AL552_238-1 & 25.03 & $21: 59$ & CTD & $54^{\circ} 36.280^{\prime} \mathrm{N}$ & $010^{\circ} 58.041^{\prime} \mathrm{E}$ & 26.00 & in the water \\
\hline AL552_239-1 & 25.03 & 22:07 & CTD & $54^{\circ} 36.024^{\prime} \mathrm{N}$ & $010^{\circ} 57.862^{\prime} \mathrm{E}$ & 25.00 & in the water \\
\hline AL552_240-1 & 25.03 & $22: 15$ & CTD & $54^{\circ} 35.750^{\prime} \mathrm{N}$ & $010^{\circ} 57.670^{\prime} \mathrm{E}$ & 23.00 & in the water \\
\hline AL552_241-1 & 25.03 & $22: 25$ & CTD & $54^{\circ} 35.348^{\prime} \mathrm{N}$ & $010^{\circ} 57.325^{\prime} \mathrm{E}$ & 18.00 & in the water \\
\hline AL552_242-1 & 25.03 & $22: 40$ & Multibeam & $54^{\circ} 36.146^{\prime} \mathrm{N}$ & $010^{\circ} 57.671^{\prime} \mathrm{E}$ & 24.00 & profile start \\
\hline AL552_243-1 & 26.03 & $1: 41$ & CTD & $54^{\circ} 37.123^{\prime} \mathrm{N}$ & $010^{\circ} 58.062^{\prime} \mathrm{E}$ & 26.00 & in the water \\
\hline AL552_244-1 & 26.03 & $3: 47$ & CTD & $54^{\circ} 37.588^{\prime} \mathrm{N}$ & $010^{\circ} 56.115^{\prime} \mathrm{E}$ & 24.00 & in the water \\
\hline AL552_245-1 & 26.03 & $8: 12$ & CTD & $54^{\circ} 38.119^{\prime} \mathrm{N}$ & $010^{\circ} 56.397^{\prime} \mathrm{E}$ & 21.00 & in the water \\
\hline AL552_246-1 & 26.03 & $11: 19$ & SES2000 & $54^{\circ} 37.930^{\prime} \mathrm{N}$ & $010^{\circ} 56.937^{\prime} \mathrm{E}$ & 22.00 & profile start \\
\hline AL552_247-1 & 26.03 & $12: 33$ & SES2000 & $54^{\circ} 37.904^{\prime} \mathrm{N}$ & $010^{\circ} 56.666^{\prime} \mathrm{E}$ & 23.00 & profile start \\
\hline AL552_248-1 & 26.03 & $13: 11$ & Multibeam & $54^{\circ} 37.150^{\prime} \mathrm{N}$ & $010^{\circ} 57.087^{\prime} \mathrm{E}$ & 27.00 & profile start \\
\hline AL552_249-1 & 26.03 & $13: 53$ & CTD & $54^{\circ} 37.584^{\prime} \mathrm{N}$ & $010^{\circ} 57.105^{\prime} \mathrm{E}$ & 24.00 & in the water \\
\hline AL552_250-1 & 26.03 & 14:04 & UW Video & $54^{\circ} 37.594^{\prime} \mathrm{N}$ & $010^{\circ} 57.056^{\prime} \mathrm{E}$ & 24.00 & in the water \\
\hline AL552_250-1 & 26.03 & $14: 12$ & UW Video & $54^{\circ} 37.587^{\prime} \mathrm{N}$ & $010^{\circ} 57.032^{\prime} \mathrm{E}$ & 24.00 & profile start \\
\hline AL552_251-1 & 26.03 & $15: 14$ & UW Video & $54^{\circ} 37.319^{\prime} \mathrm{N}$ & $010^{\circ} 56.592^{\prime} \mathrm{E}$ & 26.00 & in the water \\
\hline
\end{tabular}




\begin{tabular}{|l|l|l|l|l|l|l|} 
AL552_251-1 & 26.03 & $15: 17$ & UW Video & $54^{\circ} 37.311^{\prime} \mathrm{N}$ & $010^{\circ} 56.580^{\prime} \mathrm{E}$ & 26.00 \\
\hline
\end{tabular}

\section{Data and Sample Storage and Availability}

Sediment samples and core material will be stored at Ifg CAU Kiel and is available for further analysis. Digital data is stored on the groups severs and will be subject to further analysis.

\section{Acknowledgements}

We thank the captain Jan Lass and the crew of AL 552 for the interesting and successful cruise. 